\title{
Seasonal dynamics of organic carbon and nitrogen in biomasses of microorganisms in arable Mollisols affected by different tillage systems
}

\section{Y.S. Kravchenko ${ }^{1,2}$, Xingyi Zhang ${ }^{2}$, Chun-yu Song ${ }^{2}$, Wei Hü ${ }^{2, *}$, A.V. Yarosh ${ }^{1}$, O.V. Voitsekhivska ${ }^{3}$}

${ }^{1}$ National University of Life and Environmental Sciences of Ukraine, 15, Heroyiv Oborony Str., Kyiv, Ukraine, 03041, kravch@ nubip.edu.ua (Y.K.), yaroshanna@ukr.net (A.Y.)

${ }^{2}$ Northeast Institute of Geography and Agricultural Ecology, 138 Harping RD, Harbin, P.R.China, 150081, zhangxy@iga.ac.cn (X.Z.), cys@iga.ac.cn (C.S.), huwei@iga.ac.cn (W.X.)

${ }^{3}$ Taras Shevchenko National University of Kyiv, Institute of Biology and Medicine, Volodymyrska st., 64/13, Kyiv, 01601, Ukraine, matushka@i.ua (O.V.)

*Correspondence: huwei@iga.ac.cn

Abstract: Tillage has been reported to induce seasonal changes of organic carbon $\left(\mathrm{C}_{\text {micro }}\right)$ and nitrogen $\left(\mathrm{N}_{\text {micro }}\right)$ in biomass of microorganisms. Soil microorganisms execute such ecosystem functions as: it is an immediate sink of labile biophil elements; it is an agent of a conversion, catalysis and synthesis of humus substances; it transforms soil contaminants into non-hazardous wastes; it participates in soil aggregation and pedogenesis as a whole. However, the seasonal turnover of microorganisms on arable lands in temperate ecosystems has not been investigated on a relevant level. Hence, we aimed to study the dynamics of such soil microbial biomass patterns as: $\mathrm{C}_{\text {micro }}, \mathrm{N}_{\text {micro }}$, microbial index $\left(\mathrm{MI}=\left(\mathrm{C}_{\text {micro }} / \mathrm{C}_{\mathrm{TOC}}\right) \cdot 100\right.$, $\%$ ) and $\mathrm{CO}_{2}-\mathrm{C}$ emission on the background of 9 years of tillage and 22 years of abandoned $(\mathrm{Ab})$ and fallow $(\mathrm{F})$ usage.

Our study was conducted on a long-term experimental site on a Mollisol in the northeast China. The maximum $\mathrm{C}_{\text {micro }}$ and $\mathrm{N}_{\text {micro }}$ content was found: at the beginning of the growing season - in 0-10-; in mid-July - in 20-40 cm layers, while the minimum - in August-October. The $\mathrm{C}_{\text {micro }}$ content ranged from 577.79- and 381.79 $\mathrm{mg}^{-1} \mathrm{~kg}^{-1}$ under $\mathrm{Ab}$ in spring to 229.53- and $272.86 \mathrm{mg}^{-1} \mathrm{~kg}^{-1}$ in autumn under CT (conventional tillage) and $\mathrm{F}$ in $0-10-$ and $10-20 \mathrm{~cm}$ layers, respectively. The amplitude of $\mathrm{N}_{\text {micro }}$ content changes was several times lower comparatively to $\mathrm{C}_{\text {micro }}$. The smallest quartile range ( $\mathrm{IQR}_{0.25-0.75}$ ) of such changes was under: no-till (NT) and $\mathrm{Ab}$ in 0-10-, NT and F - in 10-20- and CT - in 20-40 cm layers. The widest $\mathrm{C}_{\text {micro }}$ : $\mathrm{N}_{\text {micro }}$ ratio was found at $\mathrm{F}$ and $\mathrm{CT}$ - in 0-20- and CT and rotational tillage (Rot) - in $20-40 \mathrm{~cm}$ layers. MI dynamics resembled the trends of $\mathrm{C}_{\text {micro }}$ and $\mathrm{N}_{\text {micro }}$ and changed from $0.72 \pm 0.168$ - to $2.00 \pm 0,030 \%$. The highest part of $\mathrm{C}_{\text {micro }}$ in $\mathrm{C}_{\text {TOC }}$ was at $\mathrm{Ab}$ $(1.82 \pm 1.85 \%)$ and NT $(1.66 \pm 1.52 \%)-$ in $0-10-; \mathrm{Ab}(1.23 \pm 1.27 \%)$ and NT (1.29 $\pm 1.32 \%)-$ in $10-20-$ and $-\mathrm{Ab}(1.19 \pm 1.09 \%)$ and $\mathrm{F}(1.11 \pm 1.077 \%)-$ in $20-40$ $\mathrm{cm}$ layers, correspondingly. The Pearson's correlation coefficient between $\mathrm{C}_{\text {micro }}$ and $\mathrm{C}_{\mathrm{TOC}}$ increased from the upper 0-10- to the lower 20-40 cm layer, it was "strong" and "high" between $\mathrm{C}_{\text {micro }}$ and $\mathrm{C}_{\mathrm{TOC}}$. Different use of Mollisol affected the amplitude of $\mathrm{C}_{\text {micro }}$ and $\mathrm{N}_{\text {micro }}$ seasonal changes, but it didn't change their trend. Our results suggest 
the key role of $\mathrm{Ab}$ and $\mathrm{NT}$ technologies in $\mathrm{C}_{\text {micro }}$ accumulation in total organic carbon (TOC).

Keywords: Mollisol, soil organic matter, microorganisms, microbial index, crop growing season

\section{Introduction.}

Soil microorganisms conduct many biological processes in agroecosystems: transform of a soil organic carbon, nitrogen, phosphorus, sulphur and other elements into available to plants; - decompose and synthetize of organic compounds into specific humus substances; - regulate the plant health; - fulfil the numerous ecosystem functions [1]. The impact of the environment on microbial communities in arable lands is usually assessed by such integral indicator as a total microbial biomass. Microbial biomass (MB) is part of a soil living phase, composing 5-10\% from a total organic matter [2,3]. Paul [4] reported that $35 \%$ of the microbial biomass had a field-adjusted mean residence time of 7 months and the other $65 \%$ - was old with a field equivalent MRT of 14 years. Bacteria and archeobacteria are the most active in a soil rhizosphere which enriched with $>0.8 \mathrm{~mm}$ of soil pores, while mycorrhizal fungi are concentrated mainly near plant residues, forest or steppe litter [5]. The dominance of fungi over bacteria in $0-5 \mathrm{~cm}$ layer was found by $\mathrm{B}$. Butenschoen et al. [6]. F. Cotrufo et al. [7] think that the amount of soil organic substrate which transformed by micro-organisms is the main indicator which characterizes the dynamics of a soil organic substance.

A seasonal dynamics of the content of $\mathrm{C}_{\mathrm{TOC}}, \mathrm{C}_{\text {micro }}$ i $\mathrm{N}_{\text {micro }}$, correlation $\mathrm{C}_{\text {micro }}$ : $\mathrm{N}_{\text {micro }}$ indicate the trend of the transformation processes of a soil organic substance in terrestrial natural and agrarian eco-systems. An agro-ecological seasonal stability of the soils, in view of $\mathrm{C}: \mathrm{N}$ interaction of organic soil compounds, is identified by their initial parameters at the beginning and before vegetation, the amplitude or cycle nature of their seasonal changes, the content of $\mathrm{C}_{\text {TOC }}, \mathrm{C}_{\text {micro }}$ i $\mathrm{N}_{\text {micro }}$ at the end and after vegetation of agricultural crops. During the vegetation of agricultural crops both the change in the content of organic compounds of carbon and nitrogen in the soils and their structural transformations take place.

Previous studies suggested that tillage provoked changes in microbial and fungi communities. According to B. Nicolardot et al. [8] findings, bacteria were a main destructor of crop residues under CT. No-till facilitates predominating fungal biomass over bacteria for a short period [9]. Such fungi's dominance has been also found in pastures and forests $[10,11]$. V. Bailey et al. [12] explained the predominance of fungal biomass over microorganisms at no-till by features of fatty acid phospholipids (PLFAs) method. With the purpose of avoiding the difficulties in enumeration of individual microbial/fungal communities, in our research chloroform fumigation extraction method (CFE) of MB determination was used [13]. CFE method is widely used to estimate $\mathrm{MB}$ in agricultural lands as a sensitive indicator of soil sustainability [14] and soil health [15]. The MB content increases with: a soil quality improvement, manure application, mulching, using legumes in crop rotation, etc. [16].

A number of authors $[17,18]$ propose to use the MB dynamics for soil quality 
assessment. The soil MB lifetime corresponds with the rates of microbial activity in soils as well as primary changes of TOC, nitrogen and sulphur compounds indicating the starting processes of soil regeneration or degradation $[19,20]$. Seasonal changes of MB depend on: soil temperature, soil water potential, content of labile organic matter and biophilic elements, quantity and quality of plant residues, oxy-redox potential and physicochemical environmental [21]. On arable lands, soil properties and regimes are changed by agricultural practices affecting the soil MB content and dynamics. Reduced tillage and no-till accumulate plant residues, TOC and total nitrogen $(\mathrm{TN})$ at the soil surface, creating therefore a trophic layer of food for fungi and microorganisms [22], accelerating their growth and activity [23]. An amount of soil organic substrate transformed by microorganisms could be presented as a key indicator characterizing the dynamics of a soil organic matter [7]. According to S. Thiessen et al. [24], the humification coefficient (HC) depends on MB. Mineral soils with lower amount of $\mathrm{MB}$ had greater $\mathrm{HC}$ comparatively to organic soils having higher amount of MB [25]. At the same time, a research literature doesn't present complete understanding about the role of microorganisms in synthesis and stabilization of bio-molecules in soils. According to data Murphy et al. [26] and J. Rousk et al. [27], the MB did not affect the growth of SOC in soils, because the formation of specific humic substances is determined by numerous interrelated factors, such as: labile carbon and nitrogen content, plant residues quality, abiotic soil-climatic parameters, etc. [28]. The mechanism of SOM synthesis under the influence of soil MB was not disclosed yet. The soil MB dynamics as well as soil organic matter content can be indirectly assessed by the magnitude of $\mathrm{CO}_{2}$. According to Hamilton et al. [29], one hectare of crop field (corn for grain - soybean rotation) annually released 4.2 tons of $\mathrm{CO}_{2}$ per year, of which $29 \%$ were produced by bacteria, $31 \%$ - fungi, $10 \%$ - fauna and $30 \%$ - by the plant root system.

Thus, a critical assessment of the soil MB could improve our understanding of management effects on SOM early changes induced by tillage, fertilizers, rotational and other agricultural practices. There is almost no information in a newer literature describing the long-term influence of different systems of tillage and land use on the seasonal MB content and dynamics. We also hypothesized that changes in seasonal temperature and moisture under background of different tillage would lead to significant differences in the temporal distributions of the MB. For the comparative purposes, in our research we determined the trend and amplitude of the seasonal $\mathrm{C}_{\text {micro }}$ and $\mathrm{N}_{\text {micro }}$ changes in different soil layers under natural and agricultural coenoses.

\section{Materials and methods.}

\subsection{Study site and sampling}

This research was conducted during 2010-2016 at the Hailun Soil and Water Monitoring Station $\left(47^{\circ} 126^{\prime} \mathrm{N}, 126^{\circ} 38^{\prime} \mathrm{E}\right)$ of North-East Institute of Geography and Agroecology of the Chinese Academy of Sciences in Hailun City, Heilongjiang Province, North-East China. 
This area is located in a semi-arid region of the northern temperature zone and continental monsoon area (cold and arid in winter, hot and rainy in summer). Average annual precipitation is $530 \mathrm{~mm}$ with $65 \%$ occurring in June to August. Annual average temperature is $1.5^{\circ} \mathrm{C}$ with an extreme minimum temperature of $-39.5^{\circ} \mathrm{C}$ and an extreme maximum temperature of $+37^{\circ} \mathrm{C}$.

Hydro-thermal coefficient of Selyaninov (HTC) [30] was determined by the formula:

$H T C=\frac{r}{0,1 \Sigma t>10^{\circ} \mathrm{C}}$, where

$\mathrm{r}$ - sum of precipitation for the period with air temperatures exceeded $10^{\circ} \mathrm{C}$;

$0,1 \sum \mathrm{t}>10^{\circ} \mathrm{C}-$ sum of effective accumulative temperatures above $10^{\circ} \mathrm{C}$ reduced in 10 times.

The soil was a typical Mollisol (Udoll). International analogues of Chinese Mollisol are: Haplic-Luvic Phaeozems, Haplic Chernozems, Udoll Mollisols (USA) [31], leached blacksoil (Ukraine, Russia). The studied Chinese soil is characterized by a transitional "ustic" - "udic" moisture regime. The tillage systems included: 22years abandoned plot, 22-years fallow F, no-till, reduced-till (RT) to a depth of $25 \mathrm{~cm}$, convention tillage to a depth of $27-30 \mathrm{~cm}$, combined tillage (Comb) to a depth of $25-30 \mathrm{~cm}$ and a rotary tillage to a depth of $20-25 \mathrm{~cm}$.

The long-term stationary one-factor experiment was established in 2004 on a randomized complete design. Each elementary plot size was $8.4 \mathrm{~m} \mathrm{x} 40 \mathrm{~m}=336 \mathrm{~m}^{2}$, the test plot $-100 \mathrm{~m}^{2}$. The experiment was repeated three times. Soil samples were taken from 0-10-, 10-20- and 20-40 cm layers. The crop rotation consisted of soybeans and corn for grain. Crops were planted at the beginning of May, and harvested - in early October. For all tillage practices the following mineral fertilizers were provided: urea, triple superphosphate and potassium sulphate. The norms of mineral fertilizers were: $\mathrm{N}_{69.5} \mathrm{P}_{51.75} \mathrm{~K}_{15}+\mathrm{N}_{100}\left(\mathrm{CO}\left(\mathrm{NH}_{2}\right)_{2}\right)$ - for corn for grain and $\mathrm{N}_{20.25} \mathrm{P}_{51.75} \mathrm{~K}_{15}$ - for soybeans.

\subsection{Soil MB analyses}

Dry combustion of soil samples was used to determine the organic carbon content and total soil nitrogen [32]. Air-dry soil (10-15 g) with removed plant remains was ground in an agate mortar, sifted through a sieve with holes of $0.25 \mathrm{~mm}$, re-selected small organic residues with tweezers and electrostatically charged ebonite stick, the cleaned sample was poured into the "shuttle" (capsule), from which $20 \mathrm{mg}$ of sample was taken for analysis. Weighing was performed directly on the scales in an aluminium box, after weighing it was closed with an envelope and twisted, after which the sample was placed in an automatic sampler, from which it came to dry oxygen combustion at a temperature of $600-650{ }^{\circ} \mathrm{C}$ on the device Vario EL III analyzer.

The carbon content of microbial biomass $\left(\mathrm{C}_{\text {micro }}\right)$ was determined by the chloroform fumigation extraction method (CFE). This method involves the extraction of $0.5 \mathrm{M} \mathrm{K}_{2} \mathrm{SO}_{4}$ with a solution of lysis products of biomass of soil microorganisms 
that died after 24 hours of fumigation with chloroform vapor [33, 34]. Fresh soil samples had been taken no earlier than 2 hours before the start of the analysis were used for this study. Fresh soil, from which 2 soil samples of $40 \mathrm{~g}$ each were taken, was sieved through a sieve with $2 \mathrm{~mm}$ holes, and plant residues and non-soil material were removed. Each soil sample was examined for field moisture content. A soil sample intended for fumigation was transferred to an open $100 \mathrm{ml}$ beaker and placed in a desiccator. At the bottom, in the central part of the desiccator, there were: - wet paper (to prevent drying of the soil during fumigation); - $50 \mathrm{ml}$ of $10 \mathrm{~mol} \mathrm{l}^{-1} \mathrm{NaOH}$ solution in a glass of $100 \mathrm{ml} ;-40 \mathrm{ml}$ of chloroform (which does not contain ethanol) in a $100 \mathrm{ml}$ beaker with small pieces of glass (to prevent the formation of large bubbles of chloroform). The desiccator was lubricated with vaseline, covered with a ground lid (without air bubbles at the joint), and then the air was pumped out with a vacuum compressor until the chloroform began to boil. Boiling continued for 1-2 minutes, after which the desiccator tap was closed and after 2 minutes was placed for 24 hours in a thermostat with a constant temperature of $+25^{\circ} \mathrm{C}$. A day later, under the hood, the tap was opened, atmospheric air was launched, and then the lid of the desiccator was opened. Control and fumigated soil samples were transferred to a 250 $\mathrm{ml}$ flask to which $150 \mathrm{ml}$ of $0.5 \mathrm{M} \mathrm{K}_{2} \mathrm{SO}_{4}$ solution was added. The resulting suspension was shaken for 30 minutes on a rotator. The saline solution of the electrolyte - coagulator $\left(0.5 \mathrm{M} \mathrm{K}_{2} \mathrm{SO}_{4}\right)$ after the rotator was filtered into plastic bottles, closed with a lid and placed in the refrigerator for daily storage at a temperature of $+4{ }^{\circ} \mathrm{C}$ or in the freezer - for long-term storage. The content of organic carbon $\left(\mathrm{C}_{\text {micro }}\right)$ and nitrogen $\left(\mathrm{N}_{\text {micro }}\right)$ biomass of microorganisms in the obtained filtrates was determined on the device Elementar Liqui TOC II, Analyzensysteme $\mathrm{GmbH}$, Germany. The carbon content of microbial biomass was calculated by the difference between carbon in fumigated and control samples using a factor of $0.45-$ for carbon and 0.54 - for nitrogen [35, 36, 37, 38].

\subsection{Statistical analyses}

The arithmetic mean value, estimated variance, the reliable probability ( $p=$ 0.95), and the significant difference were determined by using Microsoft Excel 2016, IBM SPSS Statistics for Windows v. 20.0 (@ SPSS, Chicago, Illinois), SigmaPlot for Windows Version 14.0 (2017 Systat Software, Inc.). Mean average values and standard deviations were determined for each defined indicator. Student's t-test at the significance level $\alpha=0.05$ was used to compare the mean values. The confidence interval $(\alpha=0.01)$ was calculated by comparing sets of $\mathrm{C}_{\text {micro }}$ and $\mathrm{N}_{\text {micro }}$ values. The Bonferoni method was used to correct the errors of multiple comparisons in a oneway ANOVA test. Correlation analysis was performed according to S. Pearson.

\section{Results.}

\subsection{Seasonal $C_{\text {micro }}$ changes}

The size of the amplitude of the seasonal dynamics of organic carbon and 
nitrogen biomass of microorganisms depended on the nature of the use of Mollisol and the depth of soil sampling. The largest amplitude of seasonal changes of $\mathrm{C}_{\text {micro }}$ was observed in soil samples of the upper 0-10 cm layer of Mollisol (Fig. 1A), the smallest - in the layer of 10-20 cm (Fig. 1B). The largest values of the third quartile $\mathrm{Xn}$. (0.75) were observed for $\mathrm{Ab}$ in all soil layers. The smallest values of the first quartile Xn. (0.25) were for F in the layer $0-20 \mathrm{~cm}$ and Rot - in the layer $20-40 \mathrm{~cm}$ (Fig. 1C). The largest difference in the quartile scale ( $\left.\mathrm{IQR}_{0.25-0.75}\right)$ was observed for $\mathrm{CT}$ in the layer $0-20 \mathrm{~cm}$ and RT - in the layer $20-40 \mathrm{~cm}$. Maximum quartile amplitude of $\mathrm{C}_{\text {micro }}$ values in the range $\mathrm{IQR}_{0.10-0.90}$ was found for CT and Rot - in the layer 0-10 cm, Ab and CT - in the layer 10-20 cm and RT and Comb - in the layer 20$40 \mathrm{~cm}$. The medians, within the quartile range (IQR), tended to the lower position, thus creating a lower asymmetry of the box (boxplot). The lower position of the median indicates a tendency to decrease the amplitude of the dynamics of $\mathrm{C}_{\text {micro }}$ during the growing season. The carbon content of microorganism`s biomass gradually decreased in 0-10- and increased - in 10-40 $\mathrm{cm}$ layers from May 16 (203.08-577.79 $\left.\mathrm{mg}^{-1} \mathrm{~kg}^{-1}\right)$ to August $23\left(191.29-470.02 \mathrm{mg}^{-1} \mathrm{~kg}^{-1}\right)$ and increased in early October (207.42-518.09 $\mathrm{mg}^{-1} \mathrm{~kg}^{-1}$ ) (Fig. 2).

\subsection{Seasonal $N_{\text {micro }}$ and $C_{\text {micro }}: N_{\text {micro }}$ changes}

The dynamics curve $\mathrm{N}_{\text {micro }}$ repeated the trend of $\mathrm{C}_{\text {micro }}$ : the maximum nitrogen content of microorganism`s biomass accumulated in spring, gradually decreased until August and resumed in October (Fig. 3). The high amplitude of fluctuations in the biomass of microorganisms indicates less resistance of microbial coenoses to environmental factors. The largest amplitude of seasonal changes $\mathrm{N}_{\text {micro }}$ in $0-10-, 10$ 20- and 20-40 cm layers of arable soils was observed for: CT $-9.218 \pm 7.98 \mathrm{mg}^{-1} \mathrm{~kg}^{-}$ ${ }^{1}, \mathrm{Comb}-4.317 \pm 4.67 \mathrm{mg}^{-1} \mathrm{~kg}^{-1}$ and Rot $-2.23 \pm 4.32 \mathrm{mg}^{-1} \mathrm{~kg}^{-1}$. The ratio of $\mathrm{C}_{\text {micro }}$ : $\mathrm{N}_{\text {micro }}$ in arable soils increased rapidly from July 12 to August 23 and had the highest peak in 0-10-, 10-20- and 20-40 cm layers by CT (10.10 $\pm 0.81 \%)$, CT $(10.88 \pm 1.11$ $\%)$ and Rot (12.54 $\pm 1.41 \%$ ) (Fig. 4). On the average per season, the highest value of the ratio $\mathrm{C}_{\text {micro }}: \mathrm{N}_{\text {micro }}$ was observed for $\mathrm{F}, \mathrm{CT}$ and Rot, the lowest - for Ab and NT.

The highest content oforganic carbonand nitrogen and the narrowest correlation $\mathrm{C}_{\text {micro }}: \mathrm{N}_{\text {micro }}$ in 0-20-cm Millisol layer were observed under Ab and NT, contrary correlation was under CT, F and Rot. In 20-40-cm layer the widest correlation $\mathrm{C}_{\text {micro }}$ : $\mathrm{N}_{\text {micro }}$ was formed under RT.

\section{correlation \\ 3.3. A correlation analysis and determination of the coefficients of linear of K. Pearson}

To establish the relationship between the change in carbon of microorganism's biomass and the dynamics of organic carbon of the soil during the growing season, we conducted a correlation analysis and determined the coefficients of linear correlation of K. Pearson (Table 1). It was found out that the positive correlation 
between the two parameters increased from the upper 0-10 $\mathrm{cm}$ layer to the lower - 20$40 \mathrm{~cm}$ layers. The value of the correlation coefficient between $\mathrm{C}_{\text {micro }}$ and $\mathrm{C}_{\text {org }}$ in the 0 $10 \mathrm{~cm}$ layer of Hailun Mollisol according to the "Chaddock Table" is estimated mainly as: "moderate" and "significant". "Strong" (0.70-0.89) and single "high" (0.90-0.99) negative correlations in Hailun Mollisol were found between: $\mathrm{F} \mathrm{C}_{\text {org }}$ and RT $\mathrm{C}_{\text {micro }}, \mathrm{Ab} \mathrm{C}_{\text {micro }}$ and $\mathrm{F} \mathrm{C}_{\text {org }}$, Rot $\mathrm{C}_{\text {org }}$ and RT $\mathrm{C}_{\text {micro }}$, Comb $\mathrm{C}_{\text {org }}$ and Comb $\mathrm{C}_{\text {micro }}-$ in 0-10 cm layer, NT $\mathrm{C}_{\text {micro }}$ and $\mathrm{CT} \mathrm{C}_{\text {org }}, \mathrm{F} \mathrm{C}_{\text {org }}$, Comb $\mathrm{C}_{\text {org }}$ and Rot $\mathrm{C}_{\text {org }} ; \mathrm{CT} \mathrm{C}_{\text {micro }}$ and Comb $\mathrm{C}_{\text {org }}$ and Rot $\mathrm{C}_{\text {org }} ; \mathrm{F} \mathrm{C}_{\text {micro }}$ and Comb $\mathrm{C}_{\text {org }}$ and Rot $\mathrm{C}_{\text {org }}$; Rot $\mathrm{C}_{\text {org }}$ and Comb

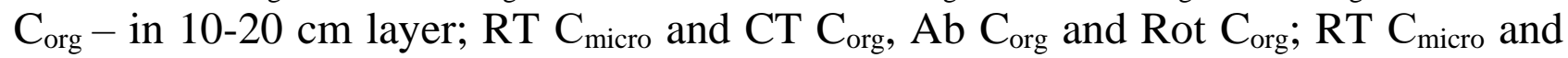
$\mathrm{NT} \mathrm{C}_{\text {org }}, \mathrm{CT} \mathrm{C}_{\text {org }}, \mathrm{Ab} \mathrm{C}_{\text {org }}$ and Rot $\mathrm{C}_{\text {org }}, \mathrm{F} \mathrm{C}_{\text {micro }}$ and RT $\mathrm{C}_{\text {org }}$, Comb $\mathrm{C}_{\text {micro }}$ and $\mathrm{CT} \mathrm{C}_{\text {org }}$ and Rot $\mathrm{C}_{\text {org }}$; Rot $\mathrm{C}_{\text {micro }}$ and $\mathrm{NT} \mathrm{C}_{\text {org }}, \mathrm{CT} \mathrm{C}_{\text {org }}, \mathrm{Ab} \mathrm{C}_{\text {org }}$, Comb $\mathrm{C}_{\text {org }}$ and Rot $\mathrm{C}_{\text {org }}$ - in $20-40 \mathrm{~cm}$ layer.

\section{Discussion}

Seasonal changes in the biomass of microorganisms, which is determined by the method of fumigation-extraction, can occur 2-4 or more times [39, 40, 41]. Moreover, with agricultural use of soils, the seasonal dynamics of microorganism`s biomass is more pronounced compared to natural coenoses [42]. According to the results of our research, the content of organic carbon and nitrogen has been changed during the season: the highest content of $\mathrm{C}_{\text {micro }}$ and $\mathrm{N}_{\text {micro }}$ was observed in mid MayJuly, decreased by the end of August and recovered in October (Fig. 2 - 3). This pattern was observed in the Mollisol of Northeast China [43, 44]. The speed of microbial circulation in soils, in addition to abiotic factors, is also affected by the presence of readily available humic substances, detritus, colloid desorption products and transformation of plant residues, plant root system secretions, products of hydrolysis of organic polymers, etc. [45].

\subsection{Temperature and moisture effect on the soil microbial biomass amount}

Previous studies [46, 47] suggested that seasonal variations in MB are driven such abiotic factors as temperature and moisture. The district of Hailun city is in the area of a continental climate of eastern outskirts of Eurasia. Here the area of a monsoon type of a climate with significant temperature amplitude is formed. In the years of 2010-2016 the temperatures higher than 0-; +5- and $+10{ }^{\circ} \mathrm{C}$ were recorded on March 26, April 7 and 28 (Fig. 6). At the end of April Mollisol gets heated very much which leads to the temperature increase over $+10{ }^{\circ} \mathrm{C}$ in a superficial soil layer on April 22-26. However, in the first decade of May, a short-term cold period was recorded, which, on the average, affected the decrease of an average monthly temperature by $0.3-2.2{ }^{\circ} \mathrm{C}$. Beginning from the last decade of May till the second decade of September the air temperature went up intensively without any significant cold periods. From May till October in 2010-2016 the general amount of precipitation changed from $304.3-523.9 \mathrm{~mm}$. The largest amount of precipitation was recorded in July, and it exceeded this indicator in May and August by 1.8-4.7 and 2.3-5.7 
times. On the average, in $2010-2016 \sum \mathrm{t}>10{ }^{\circ} \mathrm{C}$ and $\mathrm{HTC}$ amounted to $3210.91{ }^{\circ} \mathrm{C}$ and 1.36, respectively. High average monthly temperatures and sufficient amount of precipitation created optimal conditions for the formation of bio-mass and for corn grain and soybeans to fill.

The technologies of soil cultivation (tillage) have a direct and indirect effect on the dynamics and reserves of moisture in the soils [48]. The increase of moisture content and reserves under mould-boardless/conservation tillage is associated with the reduction of evaporation, the increase of the number of agronomical valuable and water-resistant aggregates [49], the decrease of the density of "an arable sole", the increase of humus content [50], a better porosity and infiltrating ability of the soils, soil-protective properties of the soil surface during heavy rain storms and signs of water erosion [51]. The use of plowless/conservation tillage supports the correlation between density and porosity similar to virgin lands [52, 53]. A higher moisture content of the soils under soil-protective technologies improves the transport of nutrient elements, calcium and microelements through a plant root system [54].

The trend of the dynamics of $\mathrm{C}_{\text {micro }}$ content during a vegetative period depended more on the soil moisture content and temperature and it depended less on soil management techniques. From May to August the decrease in $\mathrm{C}_{\text {micro }}$ and $\mathrm{N}_{\text {micro }}$ content went along with the reduction of the moisture content and the temperature rise in upper layers of Mollisol (Fig. 7), higher water consumption by plants, higher evapotranspiration. From May 16 till July 12 , in a layer $20-40 \mathrm{~cm}, \mathrm{C}_{\text {micro }}$ and $\mathrm{N}_{\text {micro }}$ content increased (Fig. 2) together with the increase of moisture content in this layer and lower soil temperatures, as compared with the upper layer 0-20 cm (data not shown).

The largest decrease of the moisture content on the background of high soil temperatures (Fig. 7) and $\mathrm{C}_{\text {micro }}$ and $\mathrm{N}_{\text {micro }}$ (Fig. 2 and 3) in all layers of Mollisol at the end of August was accompanied by the widest correlation of $\mathrm{C}_{\text {micro }}: \mathrm{N}_{\text {micro }}$ (Fig. 4). This effect is associated with the following: - physical and chemical catalysis of humus compounds under the effect of high temperatures, solar radiation (ultra-violet radiation) and air oxidation [55]; - dehydro-condensation of phenols via the mechanism of free radicals; - non-exchangeable fixation of $\mathrm{C}-\mathrm{CO}_{2}$ of soil air in hetero-cyclic aromatic compounds of humus substances; - poly-condensation and complex-formation of organic compounds, carbon; - oligo- and polymerization of poly-phenols, pyrogallols, hydroquinones, catechines with their further fixation in stable fractions of humus substances [56]; - the increase of the sizes of humus molecules by means of creating macro-molecular polymers or super-molecular biomonomers $[57,58]$.

In a fall-winter period, after the harvest time, the process of a continuous biological and abiotic stabilization and the restoration of the compounds of organic carbon and nitrogen take place. The content of $\mathrm{C}_{\text {micro }}$ and $\mathrm{N}_{\text {micro }}$ increases (Fig. 2 and 3 ) and the correlation of $\mathrm{C}_{\text {micro }}$ i $\mathrm{N}_{\text {micro }}$ gets narrower (Fig. 4). Hydrophilic organic components enriched with carbon and nitrogen, which were formed as a result of the decay of post-harvest residues, are linked with hydrophobic centers of humic substances and stabilized in disperse and water-resistant fractions of soil aggregates [59]. In a cold autumn period, newly-formed humus substances, organo-genic 
monomers, products of acid hydrolysis of nitrogen-containing substances (amino acids, amines, amides) penetrate into lower soil layers together with gravitation water, get connected with mineral soil components; heterotrophic fixation of soil carbon dioxide, condensation of organic $\mathrm{C}$ and $\mathrm{N}$ take place in highly molecular structures.

\section{2. $\mathrm{CO}_{2}$-C emission in Mollisol under different tillage systems}

The intensity of the soil microbial respiration $\left(\mathrm{C}-\mathrm{CO}_{2}\right)$ is the most dynamic indicator which describes the changes of labile carbon of the soils and it can serve as an important criterion for the estimation of the general biological activity of a coenosis microbial component $[60,61]$. The observation of the emission of carbon dioxide showed different production of $\mathrm{CO}_{2}-\mathrm{C}$ Mollisol during vegetation (Fig. 8). At the end of April, before sowing, various ridge tools were used at $25-\mathrm{cm}$ depth which enhanced the activation of the mineralization processes and a short-term entry of $\mathrm{CO}_{2}-\mathrm{C}$ into the atmosphere. The effect of "hot spot" [62], which occurred immediately after plowing, continued for several days and had no effect on the examination of carbon dioxide emission which was done on May 16. The smallest amount of emitted $\mathrm{CO}_{2}$ for the whole season was recorded in May. At this time gaseous carbon emitted the most, namely: $\mathrm{Ab}\left(1.48 \pm 0.25 \mathrm{~kg}^{-1} \mathrm{ha}^{-1} \mathrm{hr}^{-1}\right)$, Rot $(0.75 \pm$ $\left.0.39 \mathrm{~kg}^{-1} \mathrm{ha}^{-1} \mathrm{hr}^{-1}\right)$, CT $\left(0.64 \pm 0.43 \mathrm{~kg}^{-1} \mathrm{ha}^{-1} \mathrm{hr}^{-1}\right)$. The application of deep loosening under $\mathrm{CT}$ and Rot facilitated the fast warming of an arable soil layer, the enhancement of oxidative processes and $\mathrm{CO}_{2}$ diffusion from lower soil layers. The increase of the $\mathrm{CO}_{2}-\mathrm{C}$ emission in natural and agrarian conenoses took place in a summer period.

The highest peak of $\mathrm{CO}_{2}-\mathrm{C}$ emission was recorded in the mid of July (Fig. 8). This indicator had the highest meaning at $\mathrm{Ab}$, Rot, $\mathrm{CT}$, Comb. The increase of $\mathrm{CO}_{2}$ emission from the mid of May till the mid of July was associated with the cultivation of the sown area which was done twice, the application of urea as top dressing, the intensive accumulation of bio-mass of micro-organisms and a plant root system, the activation of enzymatic activity. More root exudates and plant fallings, products of decarboxylation of carbonates and humus substances came into the soil under the effect of high soil temperature and moisture (the effect of monsoon rains).

At the end of August and the beginning of October the amount of emitted $\mathrm{CO}_{2}$ $\mathrm{C}$ decreases (Fig. 8). During this period the highest amplitude of $\mathrm{CO}_{2}-\mathrm{C}$ dynamics was recorded under CB $\left(0.58 \pm 0.92 \mathrm{~kg}^{-1} \mathrm{ha}^{-1} \mathrm{hr}^{-1}\right)$ and Comb $\left(0.68 \pm 1.01 \mathrm{~kg}^{-1} \mathrm{ha}^{-1} \mathrm{hr}^{-}\right.$ $\left.{ }^{1}\right)$. The highest amplitude of seasonal $\mathrm{CO}_{2}-\mathrm{C}$ changes was observed under $\mathrm{CT}$ and Comb. The following was typical for this time: the functioning and development of microorganisms worsened, a soil temperature, bio-mass and the activity of a plant root system decreased, a less amount of a hydrophilic organic substrate entered the soil as well as that of non-specific and labile humic substances, soil density increased, an arable soil layer lost moisture available for plants. In this period all the mentioned factors reduced the amount of emitted $\mathrm{CO}_{2}-\mathrm{C}$ from Mollisol surface by $0.15-0.68 \mathrm{~kg}^{-1}$ $\mathrm{ha}^{-1} \mathrm{hr}^{-1}$. After harvesting, a large number of plant residues entered the soil which enhanced the microbiological activity and in turn the increase of $\mathrm{CO}_{2}$ emission by the 
soils. On the average per season, the largest amount of $\mathrm{CO}_{2}-\mathrm{C}$ was emitted under $\mathrm{Ab}$ $-1.38-1.53 \mathrm{~kg}^{-1} \mathrm{ha}^{-1} \mathrm{hr}^{-1}$ i Rot $-1.08 \mathrm{~kg}^{-1} \mathrm{ha}^{-1} \mathrm{hr}^{-1}$. The smallest emitted amount of $\mathrm{CO}_{2}-\mathrm{C}$ was recorded under $\mathrm{F}-0.44-0.54 \mathrm{~kg}^{-1} \mathrm{ha}^{-1} \mathrm{hr}^{-1}$.

\subsection{Tillage effect on dynamics of soil microbial biomass}

At the beginning of the growing season, there were numerous remains of the predecessor plant - soybeans and newly formed in the autumn-winter period labile humic substances. Mollisol at this time was enriched with mineral forms of nutrients due to the introduction of the main seed mineral fertilizer at the rate of $\mathrm{N}_{69.5} \mathrm{P}_{51.75} \mathrm{~K}_{15}$, followed by two feedings of urea $\mathrm{N}_{50}+\mathrm{N}_{50}$ in late April - early May. The presence of organic matter available for mineralization led to the initialization of the hydrolytic microflora (L-strategists), which was prepared for other groups of microorganisms of easily hydrolyzed substrate [63]. It was during this period that the so-called priming effect took place, which stimulated the metabolic activity of microorganisms in Mollisols [64]. As a result, in mid-May, the highest content of $\mathrm{C}_{\text {micro }}$ and $\mathrm{N}_{\text {micro }}$ was observed in the $0-10 \mathrm{~cm}$ layer of soil in all studied variants. The highest values of $\mathrm{C}_{\text {micro }}$ and $\mathrm{N}_{\text {micro }}$ in this period were found for: $\mathrm{Ab}(577.79 \pm 1.64$ - and $65.0 \pm 0.47$ $\left.\mathrm{mg}^{-1} \mathrm{~kg}^{-1}\right)$, NT $\left(485.43 \pm 1.97\right.$ - and $\left.52.7 \pm 0.45 \mathrm{mg}^{-1} \mathrm{~kg}^{-1}\right)$. The lowest content of organic carbon and nitrogen was observed for black fallow.

In the period from May 16 till July 12, the reduction of $\mathrm{C}_{\text {micro }}$ i $\mathrm{N}_{\text {micro }}$ content occurred, as compared with pres-sowing indicators. M.T. Kuprychenkov [65] states that a significant decrease of the content of organic $\mathrm{C}$ and $\mathrm{N}$ from spring till summer is predetermined by the intensity of oxidation processes under the effect of average daily air temperatures over $20{ }^{\circ} \mathrm{C}$ and $50-60 \%$ of soil moisture from the field capacity. At this time vegetative plants receive actively the elements of mineral nutrition from humus. Oxygen saturation of the soil takes place immediately after its spring tillage which results in the autotrophic mineralization of organic carbon compounds. According to the data of S.Yu. Bulyhina et al. [66], $\mathrm{CO}_{2}$ emission in a spring-summer period is larger by 10-25 times, as compared with the emission in a fall period, also $\mathrm{CO}_{2}$ emission under virgin lands is larger by 10-23 times as compared with the application of regular plowing. The results received in the previous research [67] show better enrichment of soil organic substance with labile nitrogen-containing organic compounds under soil conservation tillage technologies. Hence, under soil conservation tillage, the accelerated catabolic metabolism takes place on the background of higher content of organic substrates, required for depolymerization and intensive microbiological and enzymatic activity. During the first two months after a sowing period, the content of $\mathrm{C}_{\text {micro }}$ i $\mathrm{N}_{\text {micro }}$ decreases, newlyformed organic monomers are used by microorganisms, mineral compounds and even amino acids - by plants [68]. Some soil nitrogen releases from a biological cycle. The energy, released in the course of catabolism, and biological monomers are used for the synthesis of humus compounds, poly-condensation reactions and aromatization, for the formation of associative complexes at the end of August. The highest value of $\mathrm{C}_{\text {micro }}: \mathrm{N}_{\text {micro }}$ and the smallest one of $\mathrm{C}_{\text {micro }} \mathrm{C}_{\mathrm{TOC}}$ are recorded at this time.

According to Bonde et al. [69], mineralization losses of nitrogen at the 
beginning of vegetation, on the average, are larger by $55 \%$ as compared with those at the end of vegetation. Salinas-Garcia et al. [70], based on the results of the 10-year research, found out that the amplitude of seasonal changes of organic carbon under no-till was, on the average, higher by $16 \%$ as compared with its changes under other soil tillage technologies, and the largest difference of the above-mentioned changes was observed at the beginning of vegetation $(64 \%)$ and at a flowering stage (41\%). In our research, the amplitude of seasonal changes of $\mathrm{C}_{\text {micro }}$ and $\mathrm{N}_{\text {micro }}$ under NT and $\mathrm{Ab}$ in a $0-10-\mathrm{cm}$ layer (Fig. $1 \mathrm{~A}$ ) was smaller as compared with other technologies due to a lower temperature and a larger amount of moisture (Fig. 7). "Hotspot" in these treatments did not occur in the period under study which can be explained by a growing activity of mycorrhizal fungi on plant residues and the lack of serious changes of soil temperature and moisture in Mollisol, the latter is connected with growing air temperatures and a monsoon type of a climate during a vegetative period [71]. S. Frey et al. [72, 73] and O. Butenschoen [6] noted a significant predominance of fungal to bacterial biomass by no-till. The results obtained by X. Jiang et al. [74] indicate the local placing of fungal biomass in macroaggregates and biomass of microorganisms - in soil microaggregates, regardless of the method of tillage. S. Cleveland and D. Liptzin [75] believe that the high ratio of $\mathrm{C}_{\text {micro }}: \mathrm{N}_{\text {micro }}$ in soil macroaggregates by CT compared to NT, indicates insufficient nitrogen content during plowing. According to the results of our research, which are confirmed by the work of Hernández and Lopez-Hernández [76], for CT $\left(26.49-29.79 \mathrm{mg}^{-1} \mathrm{~kg}^{-1}\right)$ and F $\left(23.52-27.21 \mathrm{mg}^{-1} \mathrm{~kg}^{-1}\right)$, on average for season, the lowest amount of nitrogen accumulated in the biomass of microorganisms, which led to the widest ratio of $\mathrm{C}_{\text {micro }}: \mathrm{N}_{\text {micro }}$ by rotational treatment $(11.49 \pm 1.41)$ and black fallow $(11.43 \pm 1.09)$ (Fig. 4).

In August a total amount of a hydrophilic organic substrate, nutrient elements and the content of moisture available for plants decreased, density and soil temperature increased, the mode of ORP was characterized with maximal oxidation, tillage and the transportation of farm machinery across the field resulted in the damage of structural soil aggregates. As a result of the utilization of organic plant residues by microorganisms, fungi exudates and a plant root system, hydrophilic lowmolecular humus substances, the reduction of nutrient substrate occurs which leads to the decrease of a quantitative and species composition of micro-organisms. The competition for available nutrition elements is observed between plants and microorganisms. All the above-mentioned factors had an effect on the largest decrease of the concentration of bio-mass of soil microorganisms at the end of August. At the beginning of October, before harvesting, the re-utilization of nutrient elements into the soil takes place, the amount of plant fallings increases, which, on the background of higher amount of precipitation and average daily air temperature + $12{ }^{\circ} \mathrm{C}$, influenced the increase of bio-mass of microorganisms in Mollisol. During a cold period of the year, the correlation between bio-mass of fungi and bacteria increases. At this time one can see an active development of micellar and yeast fungi, actinomycetes, which are serious destructors of heavy-soluble heat-resistant compounds, such as cellulose and lignin [77, 78]. In spring, before vegetation, and due to the above-mentioned organisms, a large amount of labile and non-specific 
humic substances accumulate in the soils, the ones which are actively used by microorganisms and plants during a vegetative period.

MI is a sensitive indicator used in the study of primary changes in the qualitative composition of organic matter against the background of changes in soil properties [79]. The $\mathrm{C}_{\text {micro }} \mathrm{C}_{\text {TOC }}$ proportion increases as a result of active conversion of soil organic matter by soil microorganisms and decreases in degraded soils. The microbial index (MI) of soils increases in light well-moistened weakly acid soils of natural grass coenoses [80]. According to the results of our research, MI during the growing season varied from $0.72 \pm 0.168$ - to $2.00 \pm 0.030 \%$ (Fig. 5). The value of MI during the growing season varied similarly to the dynamics of $\mathrm{C}_{\text {micro }}$ and $\mathrm{N}_{\text {micro }}$. The microbial index decreased from the beginning of the growing season to the end of August and increased in early October. The highest values of MI in the $0-20 \mathrm{~cm}$ layer were observed for Ab and NT in Hailun Mollisols. In the lower 20-40 cm layer of Mollisol, MI was predominant by Ab, F and CT. During the intensive growth and development of plants, most of the labile carbon of microorganisms in the humus was formed by Ab, NT and F (in the layer of 20-40 cm). RT occupied the middle position among other options in terms of microbial index. At the beginning of October, MI increased with all tillage technologies and agrocoenoses. The microbial index gradually decreased with depth.

Based on the results of the statistical processing of the data by S. Pearson, the correlations of different dependence among the studied indicators were identified: air temperature, soil temperature and moisture at various depths, the sum of precipitation during the period under study and the effect of various tillage systems on the formation of $\mathrm{C}_{\text {мікро }}, \mathrm{N}_{\text {мікро }}$ and the formation of moisture in different soil layers. In the variants where a correlation analysis showed the availability of a strong and reliable connection, a regression analysis was made and a regression equation was composed.

Under the effect of all tillage systems (NT, RT, CT, Ab, F, Comb i Rot), direct correlation dependence between the amount of precipitation and $\mathrm{CO}_{2}$ release was determined $-\mathrm{R}=0.86 \ldots 0.98$. The strongest correlation connections were identified in the variants with Comb $\left(\mathrm{R}^{2}=0.96, \mathrm{y}=0.045 \mathrm{x}+0.6417\right)$ and $\mathrm{CT}\left(\mathrm{R}^{2}=0.93, \mathrm{y}=\right.$ $0.0406 x+0.7575)$. Also, a correlation connection of an average strength for the precipitation amount was found with $\mathrm{C}_{\text {мікро }} \mathrm{R}=0.43$ for $\mathrm{F}$.

Under the effect of all tillage systems (NT, RT, CT, Ab, F, Comb i Rot), direct correlation dependence between air temperature and $\mathrm{CO}_{2}$ release was determined $\mathrm{R}=0.61 \ldots 0.94$. The strongest correlation connection was identified in the variant with $\mathrm{Ab}\left(\mathrm{R}^{2}=0.86, \mathrm{y}=0.03456 \mathrm{x}+0.9421\right)$.

Under the effect of all tillage systems (NT, RT, CT, Ab, F, Comb i Rot), direct correlation dependence between soil temperature and $\mathrm{CO}_{2}$ release was determined $\mathrm{R}=0.63 \ldots 0.97$. The strongest correlation connection was identified in the variant with $\mathrm{Ab}\left(\mathrm{R}^{2}=0.88, \mathrm{y}=0.602 \mathrm{x}+21.93\right)$.

The effect of a temperature on the release of $\mathrm{CO}_{2}$ in NT, RT and CT at the depth of 0-10 and 10-20 cm was analyzed. A strong correlation connection between the studied parameters was identified, and $\mathrm{R}=0.82 \ldots 0.90$. The strongest correlation connection was identified with NT, at the depth of $10-20 \mathrm{~cm}\left(\mathrm{R}^{2}=0.81, \mathrm{y}=0.0497 \mathrm{x}\right.$ $+0.2023)$. 
A strong and reliable connection between the studied indicators and parameters was not found in other variants.

\section{Conclusions.}

In spite of a large number of publications related to microbial community study it is still difficult to find investigations on seasonal changes of microbial biomass influenced by agricultural practices and soil-climatic parameters. Our research has shown that environmental conditions and tillage affected trend, amount and turnover rates of soil microbial biomass. The amount of $\mathrm{C}_{\text {micro }}$ and $\mathrm{N}_{\text {micro }}$ significantly reduced from May to August and increased in October. The amplitude of seasonal $\mathrm{C}_{\text {micro }}$ and $\mathrm{N}_{\text {micro }}$ changed in 10-20 cm was lower comparatively to $0-10-$ and $20-40 \mathrm{~cm}$ layers. Microbial index was higher in May, May-July and July in: 0-10-; 10-20- and 20-40 $\mathrm{cm}$ layers, correspondently. Tillage has significantly influenced Mollisol's biological characteristics. Ab, NT and Rot yielded higher MI - in 0-20- while Ab and F and CT - in 20-40 cm layers. On the average per season, the largest amount of $\mathrm{CO}_{2}-\mathrm{C}$ in plowing soils emitted in Rot - 1.08- and CT - 0.88-0.99 $\mathrm{kg}^{-1} \mathrm{ha}^{-1} \mathrm{hr}^{-1}$, the smallest amount - in F, namely - 0.44-0.54 $\mathrm{kg}^{-1} \mathrm{ha}^{-1} \mathrm{hr}^{-1}$. A seasonable variability of $\mathrm{CO}_{2}-\mathrm{C}$ was as follows: $0.99-1.83 \mathrm{~kg}^{-1} \mathrm{ha}^{-1} \mathrm{hr}^{-1}$ - in natural coenoses, $0.33-1.51 \mathrm{~kg}^{-1} \mathrm{ha}^{-1} \mathrm{hr}^{-1}$ in arable land and $0.33-0.75 \mathrm{~kg}^{-1} \mathrm{ha}^{-1} \mathrm{hr}^{-1}-$ in fallow land. The basal respiration rate responded mainly to a soil moisture content and land use than air temperature. The $\mathrm{Ab}$ and NT increased MB in 0-20- while $\mathrm{Ab}$ and $\mathrm{Comb}-$ in 20-40 cm layers. CT, Rot and $\mathrm{F}$ significantly decreased $\mathrm{C}_{\text {micro }}$ and $\mathrm{N}_{\text {micro }}$ amount and increased $\mathrm{C}_{\text {micro }}: \mathrm{N}_{\text {micro }}$ ratio, which indicates a potential $\mathrm{N}$ limitation in Mollisol induced by these tillage. The seasonal trend of $\mathrm{C}_{\text {micro }}, \mathrm{N}_{\text {micro }}$ and $\mathrm{MI}$ in $20-40 \mathrm{~cm}$ layer varied from $0-20 \mathrm{~cm}$ layer because of its colder and wetter conditions. Our study illustrates that Mollisol's microbial community highly responded to environmental changes and agricultural practices and could indicate the beginning of soil degradation or regeneration. This phenomenon may help develop the effective strategy for the implementation of cutting-edge agricultural practices incorporated into a concept of microbial ecology.

Author Contributions: Conceptualization, Kravchenko, Y., Zhang, X., Song, Chunyu; software, Hu Wei, Yarosh, A., Voitsekhivska, O.; formal analysis, Kravchenko, Y., Voitsekhivska, O.; resources, Zhang, X., Song, Chun-yu; writing - original draft preparation Kravchenko, Y.; writing - review and editing, Kravchenko, Y.; Zhang, X., visualization, Kravchenko, Y., Yarosh, A., Voitsekhivska, O., supervision, Kravchenko, Y., Zhang, X; project administration, Zhang, X.; funding acquisition, Zhang, X. All authors have read and agreed to the published version of the manuscript.

Funding: This study was supported by the projects of the National Key Research and Development Program of China (2021YFD1500800).

Informed Consent Statement: Not applicable.

Data Availability Statement: Data will be available up on request.

Acknowledgments: The authors would like to thank the anonymous reviewers for 
their valuable comments.

Conflict of Interest: The authors declare that there are no conflicts of interest.

\section{References}

1. Chernov, T.I., Semenov, M.V. Management of Soil Microbial Communities: Opportunities and Prospects (a Review). Eurasian Soil Science, 2021, 54 (12), 18881902.

2. Dalal, R.C. Soil microbial biomass - what do the numbers really mean? Aust. J. Experim. Agric. 1998, 38, 649-665. DOI:10.1071/EA97142

3. Jenkinson, D.S.; Ladd, J.N. Microbial biomass in soil: Measurement and turnover. Biochem. 1991, 5, 415-471.

4. Paul, A. The nature and dynamics of soil organic matter: Plant inputs, microbial transformations, and organic matter stabilization. Soil Biology \& Biochemistry, 2016, 98, 109-126. http://dx.doi.org/10.1016/j.soilbio.2016.04.001.

5. Fry, S. The spatial distribution of soil biota. In: Paul E. (Ed.) Soil Microbiol., Ecol. and Biochem., fourth ed; Academic Press: San Diego, 2015, 223-244.

6. Butenschoen, O.; Poll, C.; Langel, R. Endogeic earthworms alter carbon translocation by fungi at the soil-litter interface. Soil Biol. Biochem. 2007, 39, 28542864.

7. Cotrufo, F.; Wallenstein, M.; Denef K.; et al. The molecular efficiency-matrix stabilization (MEMS) framework integrates plant litter decomposition with soil organic matter stabilization. Glob Change Biol. 2013, 19, 988-995. DOI: $10.1111 / \mathrm{gcb} .12113$

8. Nicolardot, B.; Bouziri, L.; Bastian, F.; et. al. A microcosm experiment to evaluate the influence of location and quality of plant residues on residue decomposition and genetic structure of soil microbial communities. Soil Biol. Biochem. 2007, 39, 1631-1644.

9. Helgason, B.L.; Walley, F.L.; Germida, J.J.; et. al. Fungal and bacterial abundance in long-term no-till and intensive-till soils of the Northern Great Plains. Soil Sci. Soc. Am. J. 2009, 73, 120-127.

10. Demoling, F.; Nilsson, L.; Baath, E.; et. al. Bacterial and fungal response to nitrogen fertilization in three coniferous forest soils. Soil Biol. Biochem. 2008, 40, 370-379.

11. Vries, F.T. de; Hoffland, E.; Eekeren, N. van; et. al. Fungal bacterial ratios in grasslands with contrasting nitrogen management. Soil Biol. Biochem. 2006, 38, 2092-2103.

12. Bailey, V.L.; Smith, J.L.; Bolton, H.; et. al. Fungal: bacterial ratios in soils investigated for enhanced C sequestration. Soil Biol. Biochem. 2002, 34, 997-1007.

13. Sparling, G.P. Ratio of microbial biomass carbon to soil organic carbon as a sensitive indicator of changes in soil organic matter. Aust. J. Soil Res. 1992, 30, 195207.

14. Vance, E.D., Brookes, P.C., and Jenkinson, D.S. An extraction method for measuring soil microbial biomass C. Soil Biology and Biochemistry, 1987, 19, $703-$ 707.

15. Karlen, D.L., Mausbach, M.J., Doran, J.W., et al. Soil quality: a concept, 
definition and framework for evaluation. Soil Science Society of America Journal, 1997, 61, 4-10.

16. Holmes, W.; Zak, R. Soil Microbial Biomass Dynamics and Net Nitrogen Mineralization in Northern Hardwood Ecosystems. Soil Sci. Soc. Am. J. 1994, 58, 238-243.

17. Powlson, D.S.; Brookes, P.C.; Christensen, B.T.; et al. Measurement of soil microbial biomass provides an early indication of changes in total soil organic matter due to straw incorporation. Soil Biol. Biochem. 1987, 19, 159-164.

18. Anderson, J.F.; Domsch, K.H. Quantities of plant nutrients in the microbial biomass of selected soils. Soil Sci. 1980, 130, 211-216.

19. Schmidt, S.K.; Costello, E.K.; Nemergut, D.R.; et al. Biogeochemical consequences of rapid microbial turnover and seasonal succession in soil. Ecology 2007, 88 (6), 1379-1385. DOI:10.1890/06-0164

20. Powlson, D.S.; Jenkinson, D.S. A comparison of the organic matter, biomass, adenosine triphosphate and mineralizable nitrogen contents of ploughed and directdrilled soils. J. Agric. Sci. 1981, 97, 713-721. DOI:10.1017/S0021859600037084.

21. Wright, A.L.; Hons, F.M.; Lemon, R.G. Microbial activity and soil C sequestration for reduced and conventional tillage cotton. Appl. Soil Ecol. 2008, 38, 168-173.

22. Butenschoen, O.; Poll, C.; Langel, R. Endogeic earthworms alter carbon translocation by fungi at the soil-litter interface. Soil Biol. Biochem. 2007, 39, 28542864.

23. Helgason, B.L.; Walley, F.L.; Germida, J.J. Fungal and bacterial abundance in long-term no-till and intensive-till soils of the northern great plains. Soil Sci. Soc. Am. J. 2009, 73, 120-127.

24. Thiessen, S.; Gleixner, G.; Wutzler, T.; et. al. Both priming and temperature sensitivity of soil organic matter decomposition depend on microbial biomass - an incubation study. Soil Biol. Biochem. 2013, 57, 739-748.

25. Wang, H.; Xu, W.; Hu, G.; et. al. The priming effect of soluble carbon inputs in organic and mineral soils from a temperate forest. Oecologia 2015, 178, 12391250 .

26. Murphy, C.J.; Baggs, E.M.; Morley, N.; et. al. Rhizosphere priming can promote mobilisation of N-rich compounds from soil organic matter. Soil Biol. Biochem. 2015, 81, 236-243.

27. Rousk, J.; Hill, P.; Jones, D.; et. al. Priming of the decomposition of ageing soil organic matter: concentration dependence and microbial control. Function. Ecol. 2015, 29, 285-296.

28. Shahbaz, M.; Kuzyakov, Y.; Heitkamp, F.; et. al. Decrease of soil organic matter stabilization with increasing inputs: mechanisms and controls. Geoderma 2017, 304, 76-82.

29. Hamilton S.K.; Doll J.E.; Robertson G.P. The Ecology of Agricultural Landscapes: Long-term Research on the Path to Sustainability; Oxford University Press: New York, 2015.

30. Selyaninov, G.T. About climate agricultural estimation. Proceedings on Agricultural Meteorology, 1928, 20, 165-177 (in Russian). 
31. Soil Survey Staff. Illustrated guide to soil taxonomy: Version 1.1.; USDANRCS: Lincoln, Nebraska, 2015.

32. SSTU ISO 10694-2001 Soil quality. Determination of organic and total carbon content by dry combustion (elemental analysis) (ISO 10694: 1995, IDT). K.: Stateconsumerstandard of Ukraine, 2003 (in Ukrainian).

33. Vance, E.D.; Brookes, P.C.; Jenkinson, D.S.; et. al. An extraction method for measuring soil microbial biomass C. Soil Biol. Biochem. 1987, 19, 703-707.

34. Voroney, R.; Winter, J.; Beyaert, R.; et. al. Soil microbial biomass C and N. In: Carter MR (ed): Soil sampling and methods of analysis; Canadian Society of Soil Science: Lewis, Chelsea, 1993, 277-286.

35. Wu, J.; Joergensen, R.G.; Pommering, B.; et. al. Measurement of soil microbial biomass C - an automated procedure. Soil Biol. Biochem. 1990, 22, 1167-1169.

36. Brookes, P.; Landman, A.; Pruden, G.; et. al. Chloroform fumigation and the release of soil nitrogen: a rapid direct extraction method to measure microbial biomass nitrogen in soil. Soil Biol. Biochem. 1985, 17, 837-842.

37. Jenkinson, D.S. The determination of microbial biomass carbon and nitrogen in soil. In: Wilson J.R. (ed.): Advances in Nitrogen Cycling in Agricultural Ecosystems; CAB International: Wallingford, 1988, 368-386.

38. Mueller, T.; Jensen, L.; Nielsen, N.; et. al. Turnover of carbon and nitrogen in a sandy loam soil following incorporation of chopped maize plants, barley straw and blue grass in the field. Soil Biol. Biochem. 1998, 30, 561-571.

39. Devi, N.B.; Yadava, P.S. Seasonal dynamics in soil microbial biomass C, N and $\mathrm{P}$ in a mixed-oak forest ecosystem of Manipur, North-east India. Appl. Soil Ecol. 2006, 31 (3), 220-227.

40. Edwards, K.A.; Jefferies, R.L. Inter-annual and seasonal dynamics of soil microbial biomass and nutrients in wet and dry low-Arctic sedge meadows. Soil Biol. Biochem. 2013, 57, 83-90.

41. Chernova, T.I., Zhelezova, A.D. Dynamics of soil microbial communities in different time ranges (review). Soil Science, 2020, 5, 590-600. (in Russian).

42. Lauber, C.L.; Ramirez, K.S.; Aanderud, Z.; et. al. Temporal variability in soil microbial communities across land-use types. ISME J. 2013, 7 (8), 1641-1650.

43. Sui, Y.; Xiao-guang, J.; Chong-sheng, G.; et. al. The Relationship among Organic Matter Content and Soil Microbial Biomass and Soil Enzyme Activities. Chinese J. Soil Res. 2009, 40 (5), 1036-1039.

44. Lou, Y.; Xu, M.; Wang, W.; et. al. Return rate of straw residue affects soil organic C sequestration by chemical fertilization. Soil Till Res. 2011, 113, 70-73.

45. McGill, W.; Cannon, K.R.; Robertson, J.A. Dynamics of Soil Microbial Biomass and Water-Soluble Organic C in Breton L After 50 Years of Cropping to Two Rotations. Can. J. Soil Res. 1986, 66 (1), 1-19.

46. Sun, L., Song, F., Liu, S., Cao, Q., Liu, F., Zhu, X. Integrated agricultural management practice improves soil quality in Northeast China, Archives of Agronomy and Soil Science, 2018, DOI: 10.1080/03650340.2018.1468077

47. Luo, X, Wang, MK, Hu, G, Weng B. Seasonal Change in Microbial Diversity and its Relationship with Soil Chemical Properties in an Orchard. PLOS ONE, 2019, 14(12): e0215556. https://doi.org/10.1371/journal.pone.0215556. 
48. Moraru, P., Rusu, T. Effect of tillage systems on soil moisture, soil temperature, soil respiration and production of wheat, maize and soybean crops. Journal of Food, Agriculture \& Environment, 2012, 10 (2), 445-448.

49. Pagliai, M., Raglione, M., Panini, T. et al. The structure of two alluvial soils in Italy after 10 years of conventional and minimum. Soil and Tillage Research, 1995, 34, 209-223.

50. Anderson, S., Gantzer, C, Brown, J. Soil physical properties after 100 years of continuous cultivation. J. Soil Water Conservation, 1990, 45, 117-121.

51. Sarauskis, E., Romaneckas, K., Buragiene, S. Impact of conventional and sustainable soil tillage and sowing technologies on physical-mechanical soil properties. Environmental Res. Engineer. Management, 2009, 49 (3), 36-43.

52. Josa, R. Ginovart, M., Solé, A. Effects of two tillage techniques on soil macroporosity in sub-humid environment. Agrophysics, 2010, 24, 139-147.

53. Mestelan, S., Smeck, N., Durkalski, J., Dick, W. Changes in soil profile properties as affected by 44 years of continuous no-tillage. Proc. $17^{\text {th }}$ ISTRO Conf., 28 August - 3 September. - Kiel, Germany, 2006. - P. 1135-1140.

54. NaNagara, T., Phillips, R., Leggett, J. Diffusion and mass flow of nitrate nitrogen into corn roots grown under field conditions. Agronomy J., 1976, 68, 67-72.

55. Piccolo, A. Carbon Sequestration in Agricultural Soils : A Multidisciplinary Approach to Innovative Methods. Heidleberg, Germany: Springer, 2012, 307 pp.

56. Piccolo, A., Spaccini, R., Cozzolino, V., Nuzzo, A. [et al.]. Effective carbon sequestration in Italian agricultural soils by in situ polymerization of soil organic matter under biomimetic photocatalysis. Land Degrad Dev. 2018, 29 (3), 485 - 494.

57. Nebbioso, A., Piccolo, A. Basis of a Humeomics Science: Chemical Fractionation and Molecular Characterization of Humic Biomacromolecules, 2011, $12,1187-1199$.

58. Nuzzo, A., Spaccini, R., Cozzolino, V. In situ polymerization of soil organic matter by oxidative biomimetic catalysis. Chemical and Biological Technologies in Agriculture, 2017, 4 (12), 1-6.

59. Цыбулько, Н. Углеродсеквестрирующая способность и минерализуемость органического вещества разных почв Беларуси. Журн. Белорус. гос. ун-та. Экология, 2018, 2, 110-117 (in Ukrainian).

60. Заболотний, О., Заболотна А. Мікробіологічна активність грунту при застосуванні гербіциду Мерлін. Молодий вчений, 2014. - № 2 (05), 16-20 (in Ukrainian).

61. Кешелава Р. Влияние Симазина и карагарда на биологическую активность почвы. Защита и карантин растений, 2000, 9, 49 (in Russian).

62.Fontaine, S., Mariotti, A., Abbadie, L. The priming effect of organic matter: a question of microbial competition? Soil Biol. Biochem. 2003, 35 (6), 837-843.

63. Chimitdorzhieva, E.O., Chimitdorzhieva, G.D. Carbon dynamics of microbial biomass of virgin steppe and dry steppe soils of Transbaikalia. Bulletin of KSU after name N.A.Nekrasova, 2012, 3, 16-20. (in Russian).

64. Fontaine, S., Mariotti, A., Abbadie, L. et. al. The priming effect of organic matter: a question of microbial competition? Soil Biol. Biochem, 2003, 35 (6), 837843. 
65.Куприченков, М. Сезонная динамика химических и агрохимических свойств био- и агрочернозема. Достижения науки и техники АПК. 2013, 7, 6768 (in Russian).

66.Булигін, С., Величко, В., Демиденко, О. Агрогенез чорнозему. К.: Аграрна наука, 2016, 356 с (in Ukrainian).

67.Kravchenko, Y., Rogovska, N., Petrenko, L., Zhang, X., Song, C., Chen, Y. Quality and dynamics of soil organic matter in Typical Chernozem of Ukraine under different soil tillage systems. Canadian Journal of Soil Science, 2012, 92 (3), 429438.

68.Geisseler, D., Horwath, W., Joergensen R., Ludwig B. Pathways of nitrogen utilization by soil microorganisms - A review. Soil Biol. Biochem. 2010, 42, 2058 2067.

69.Bonde, T., Schnurer, J., Rosswall, T. Microbial biomass as a fraction of potentially mineralizable nitrogen in soils from longterm field experiments. Soil Biol Biochem. 1988, 20, 447-452.

70.Salinas-Garcia, J., Hons, F., Matocha, J., Zuberer, D. Soil carbon and nitrogen dynamics as affected by long-term tillage and nitrogen fertilization. Biol Fertil Soils, 1997, 25, 182-188.

71. Kuhnert, R.; Oberkofler, I.; Peintner, U.; et. al. Fungal growth and biomass development is boosted by plants in snow-covered soil. Microbial Ecology 2012, 64(1), 79-90.

72. Frey, S.D.; Frey, S.D.; Elliot, E.T.; et. al. Bacterial and fungal abundance and biomass in conventional and no-tillage agroecosystems along two climatic gradients. Soil Biol. Biochem. 1999, 31, 573-585.

73. Frey, S.D.; Six, J.; Elliott, E.T. ; et. al. Reciprocal transfer of carbon and nitrogen by decomposer fungi at the soil-litter interface. Soil Biol. Biochem. 2003, $35,1001-1004$.

74. Jiang, X.; Alan, L.; Wright, X.; et. al. Tillage-induced changes in fungal and bacterial biomass associated with soil aggregates: A long-term field study in a subtropical rice soil in China. Appl. Soil Ecol. 2011, 48, 168-173.

75. Cleveland, C.C.; Liptzin, D. C:N:P stoichiometry in soils: is there a "Redfield ratio" for the microbial biomass? Biogeochem. 2007, 85, 235-252.

76. Hernández-Hernández, R.M.; Lopez-Hernández, D. Microbial biomass, mineral nitrogen and carbon content in savanna soil aggregates under conventional and no-tillage. Soil Biol. Biochem. 2002, 34, 1563-1570.

77. Kuhnert, R., Oberkofler, I., Peintner, U. Fungal growth and biomass development is boosted by plants in snow-covered soil. Microbial Ecology, 2012, 64(1), 79-90.

78. Schadt, C.W.; Martin, A.P.; Lipson, D.A.; et. al. Seasonal dynamics of previously unknown fungal lineages in tundra soils. Science, 2003, 301(5638), 13591361.

79. Anderson, T.H.; Domsch, K.H. Ratio of microbial biomass carbon to total organic carbon in arable soils. Soil Biol. Biochem. 1989, 21, 471-479.

80. Sparling, G.P. Ratio of microbial biomass carbon to soil organic carbon as a sensitive indicator of changes in soil organic matter. Aust. J. Soil Res. 1992, 30, 195- 
207. 

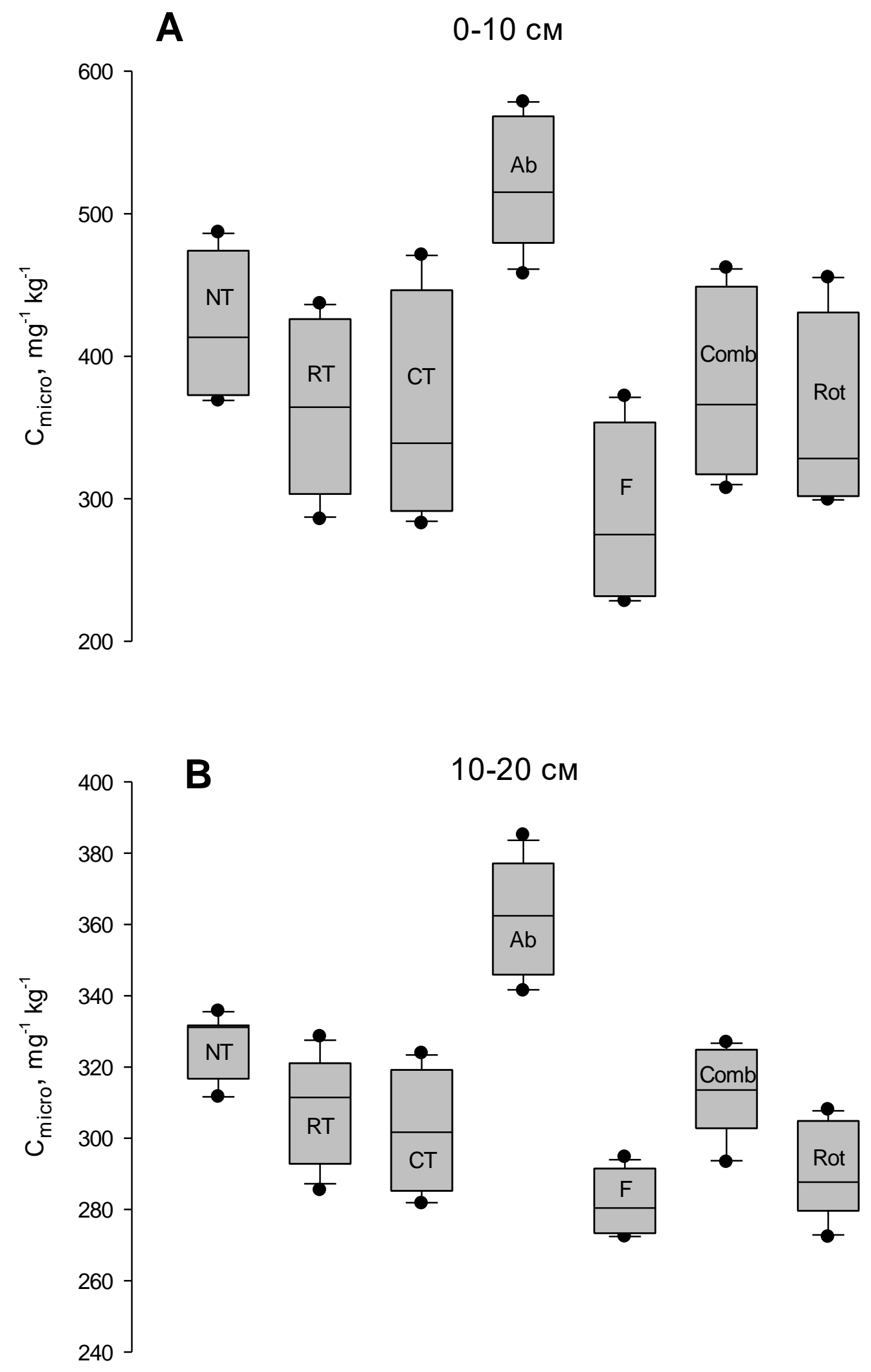


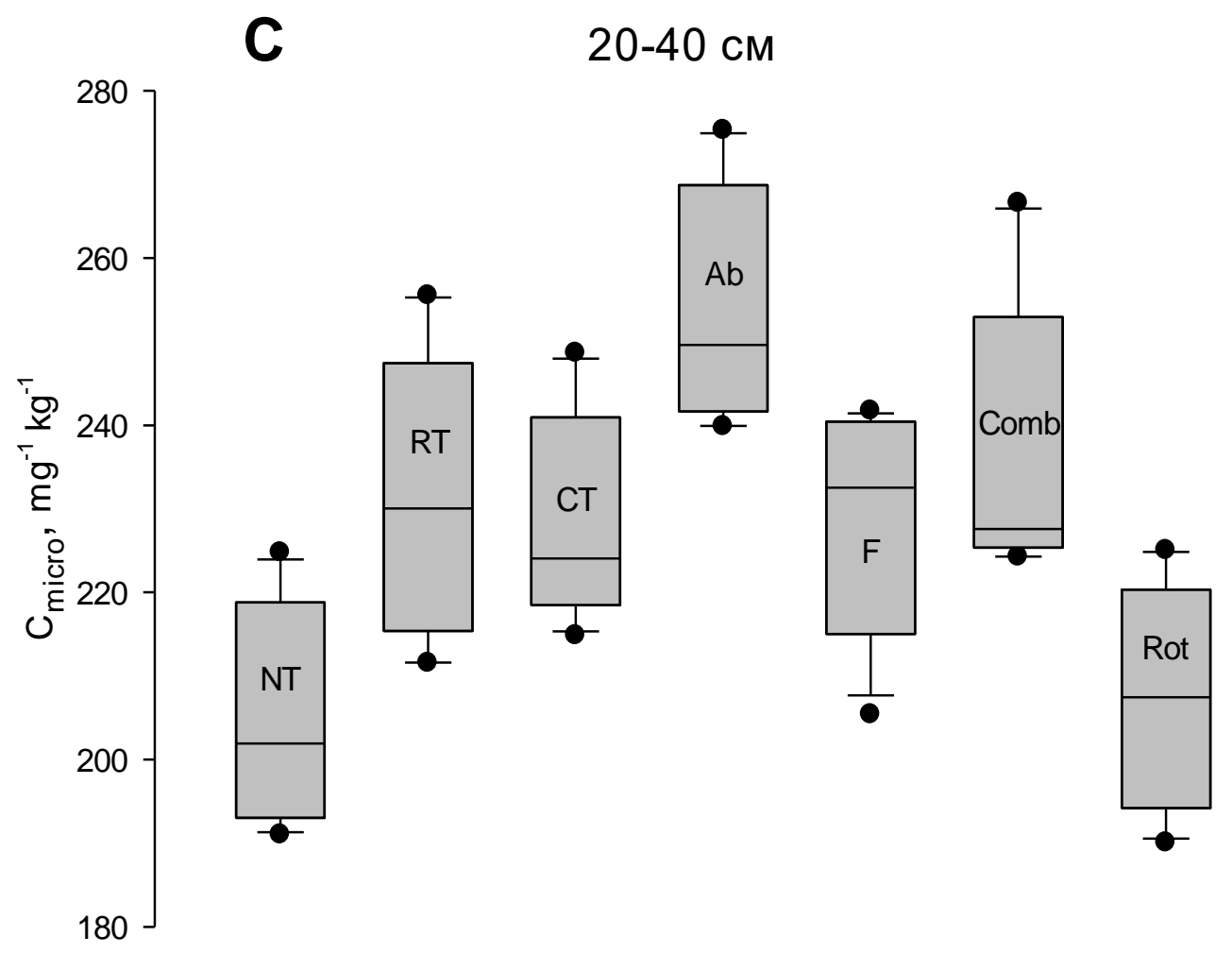

Fig. 1. Sizes of seasonal dynamics (box plot $25-75 \%$, median, $n=12$, MayJuly-August-October) $\mathrm{C}_{\text {micro }}$ in 0-10 (A), 10-20 (B) and 20-40 cm layers of Mollisol under use: conservation tillage (CT), no-till (NT), reduced (ridge) tillage (RT), rotary (Rot), combined (Comb) tillage, fallow $(\mathrm{F})$ and abandoned field ( $\mathrm{Ab}$ ) 

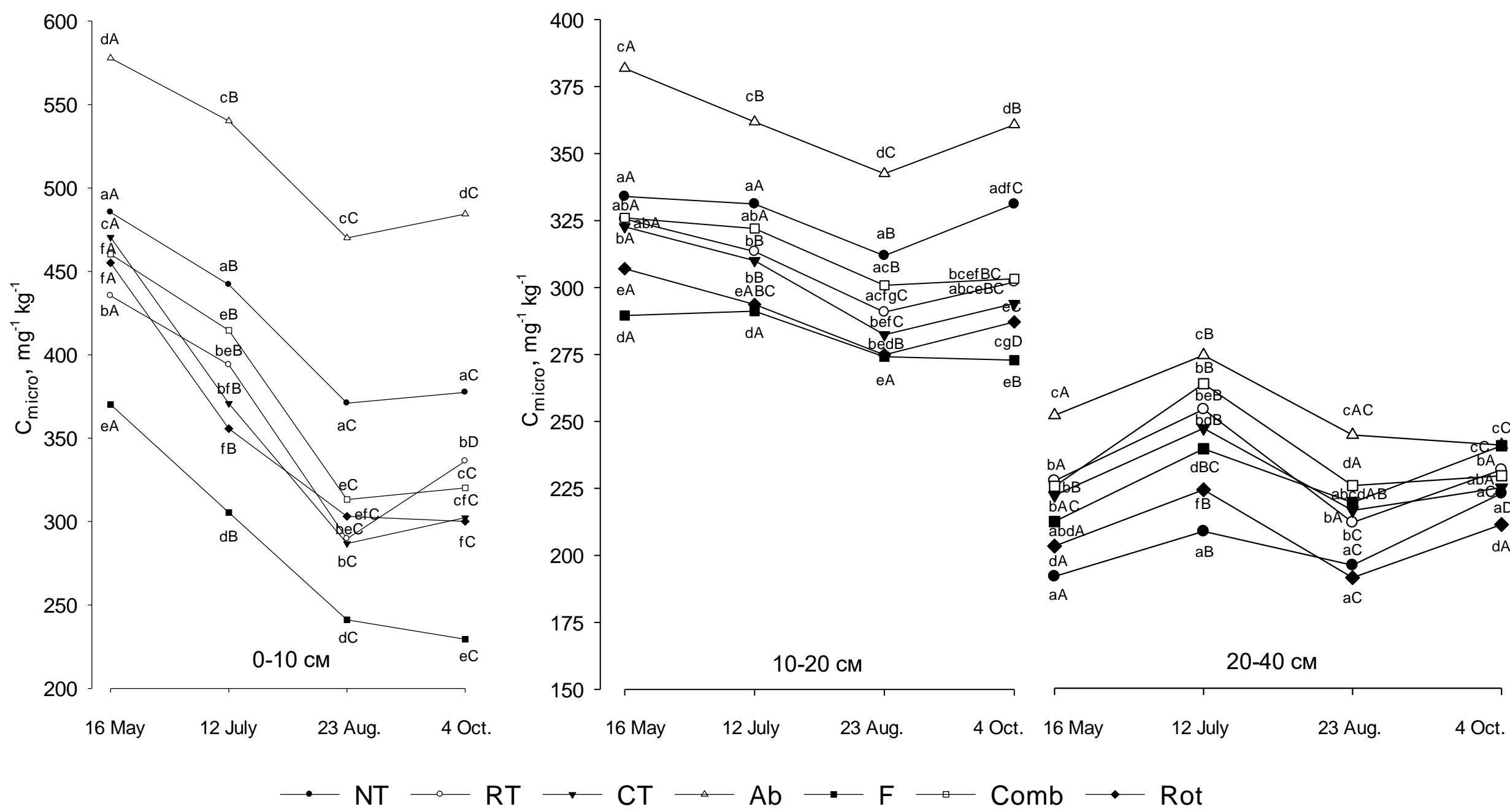

Fig. 2. Seasonal dynamics of $\mathrm{C}_{\text {micro }}$ in different of Mollisol layers under 9 years of use: conservation tillage (CT), no-till (NT), rotary (Rot), reduced (ridge) tillage (RT) and combined (Comb) tillage and fallow (F, 22 years) and abandoned field (Ab, 22 years). Average values with different lowercase letters indicate a significant difference between tillage options, uppercase

letters - a significant difference between the selection periods (HIP, $\alpha=0,05$ ) 


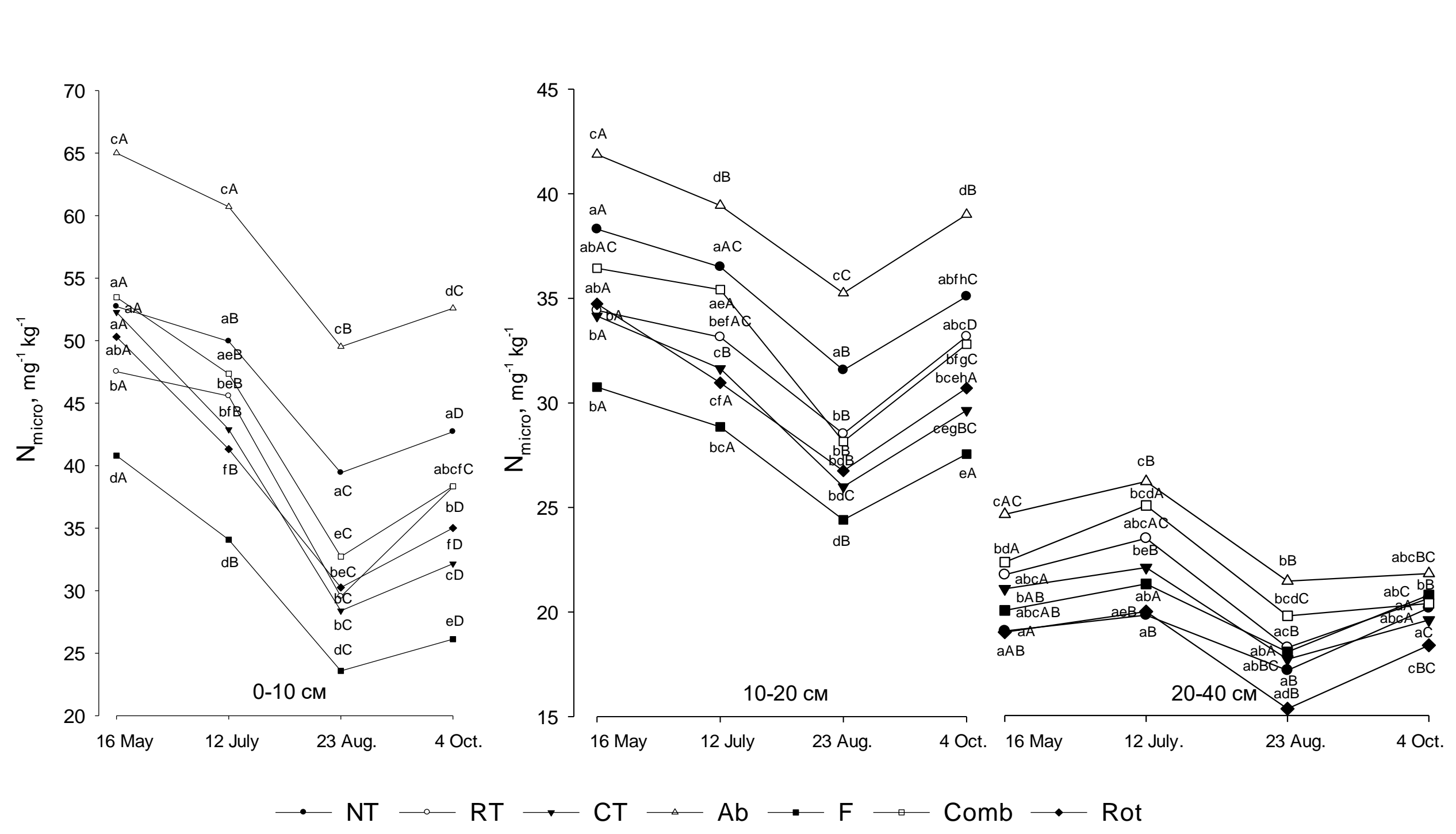

Fig. 3. Seasonal dynamics of $\mathrm{N}_{\text {micro }}$ in different of Mollisol layers under 9 years of use: conservation tillage (CT), no-till (NT), rotary (Rot), reduced (ridge) tillage (RT) and combined (Comb) tillage and fallow (F, 22 years) and abandoned field (Ab, 22 years). Average values with different lowercase letters indicate a significant difference between tillage options, uppercase letters - a significant difference between the selection periods (HIP, $\alpha=0,05)$.

(

.

.




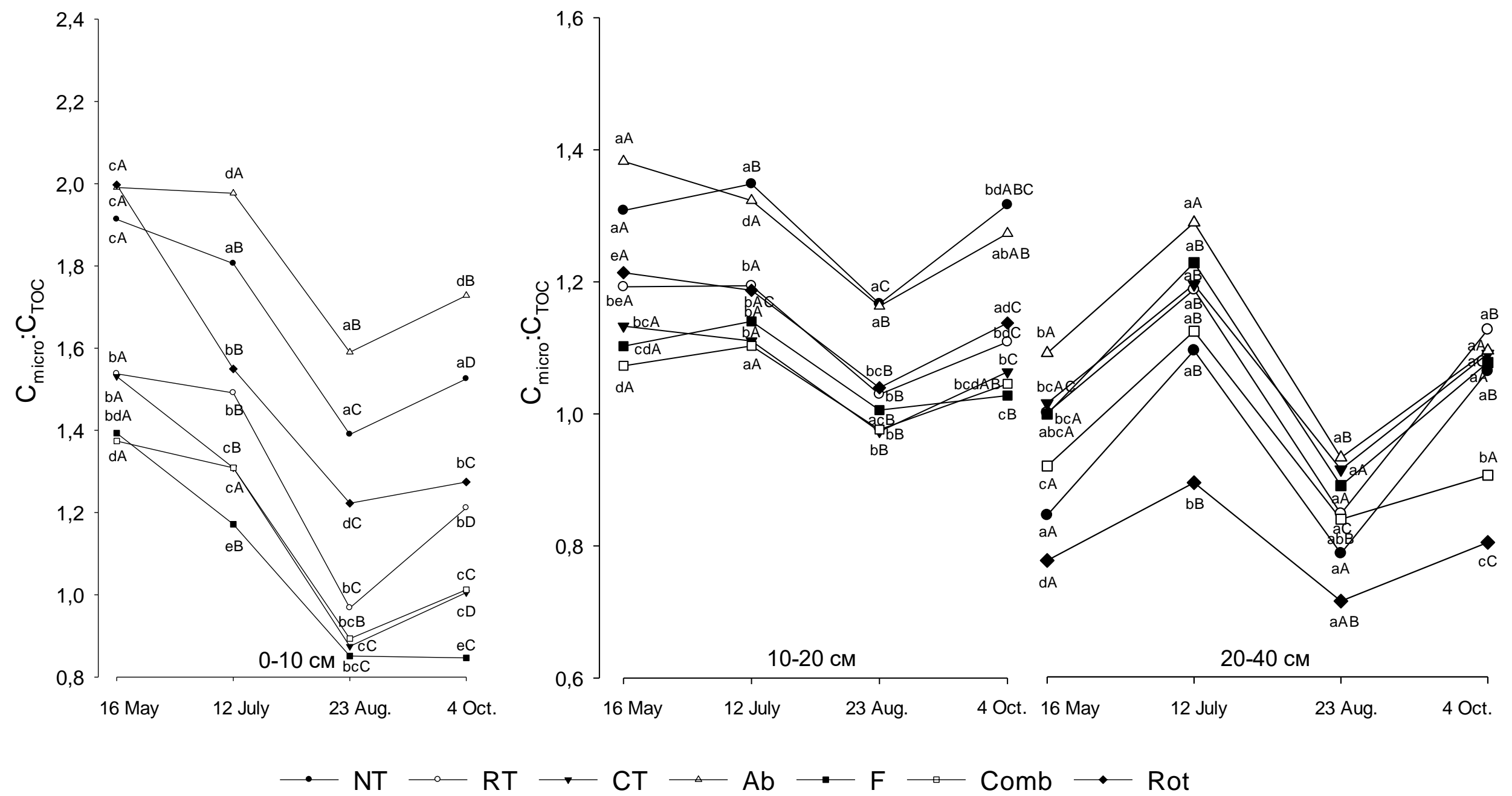

Fig. 5. MI dynamics in different layers of Mollisol under 9 years of use: conservation tillage (CT), no-till (NT), rotary (Rot), reduced (ridge) tillage (RT) and combined (Comb) tillage and fallow (F, 22 years) and abandoned field (Ab, 22 years).

Average values with different lowercase letters indicate a significant difference between tillage options, uppercase letters - a

significant difference between the selection periods (HIP, $\alpha=0,05$ ). 


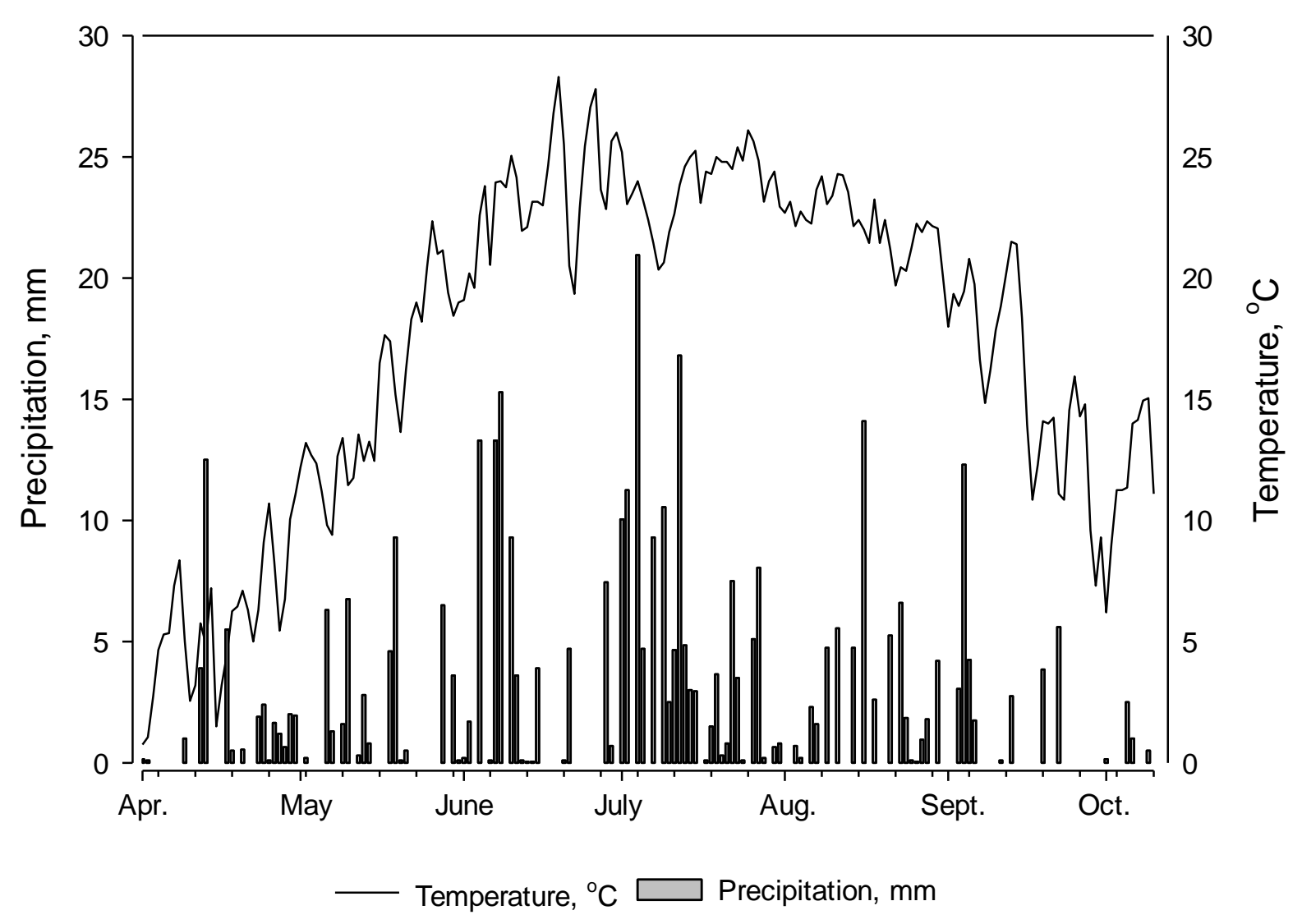

Fig. 6. Average air temperatures and precipitation in a season 2010-2016, Hailun Meteorological station, China 


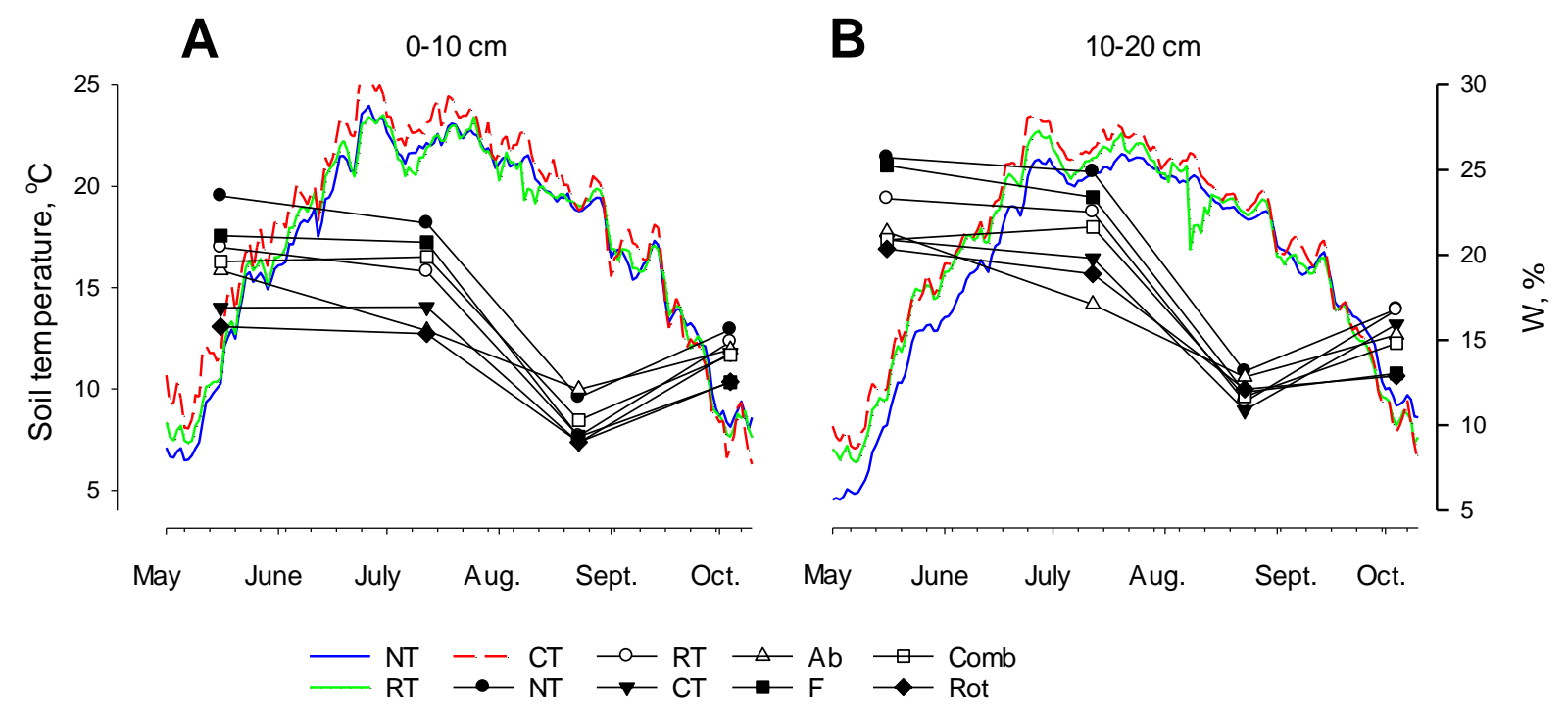

Fig. 7. Tillage effect on Mollisol temperature $\left({ }^{\circ} \mathrm{C} ; \mathrm{A}\right)$ and moisture $(\mathrm{W}, \%$; B) in 0 10- (A) and 10-20 cm (B) layers 


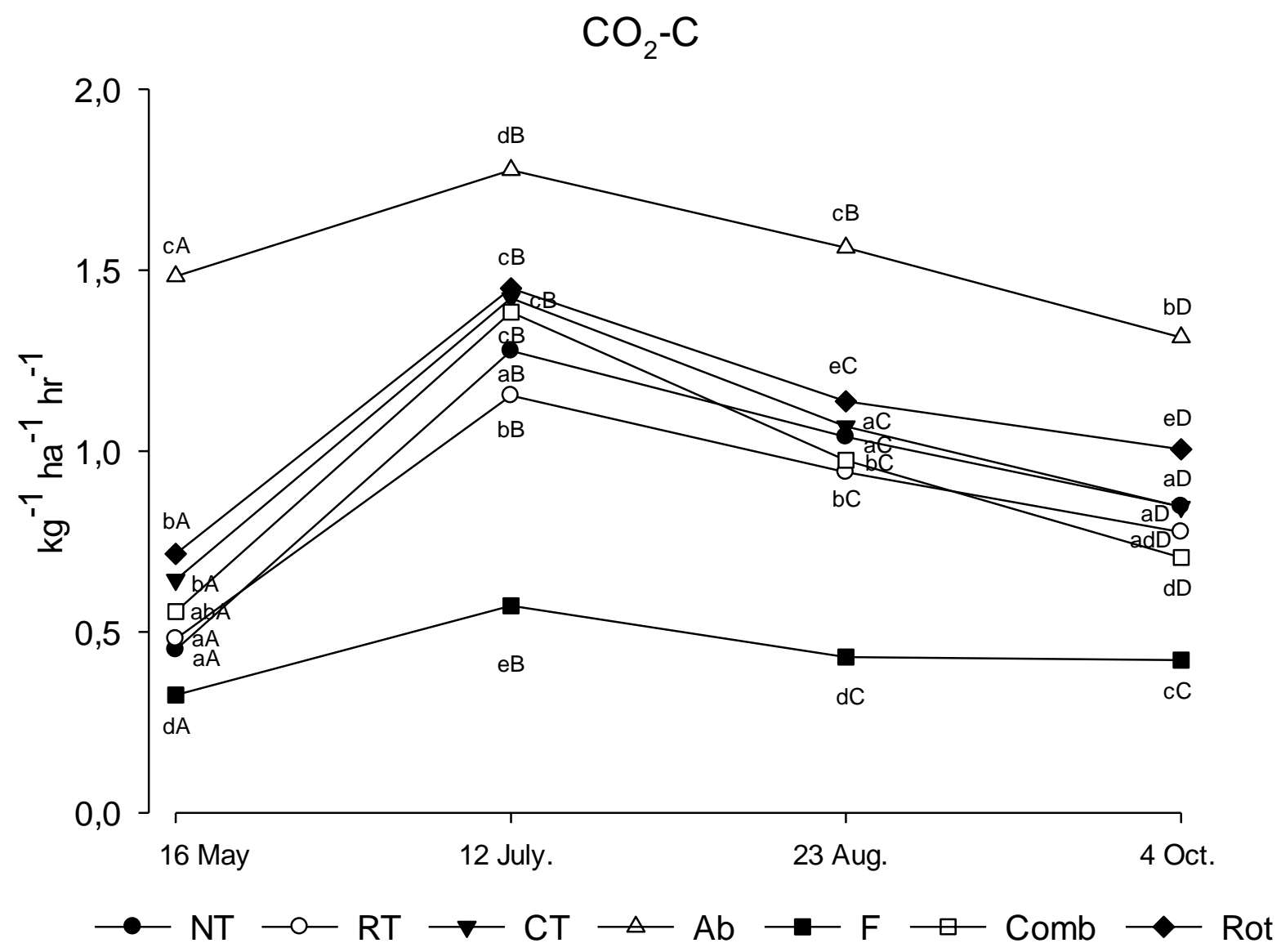

Fig. 8. Tillage effect on $\mathrm{CO}_{2}-\mathrm{C}$ emission in Mollisol 
Table 1.

\section{K. Pearson's linear correlation coefficients between $\mathbf{C}_{\text {micro }}$ and $\mathbf{C}_{\text {org }}$}

\begin{tabular}{|c|c|c|c|c|c|c|c|}
\hline Parameters & $\mathrm{NT} \mathrm{C}_{\mathrm{TOC}}$ & $\mathrm{RT} \mathrm{C}_{\mathrm{TOC}}$ & $\mathrm{CT} \mathrm{C} \mathrm{C} \mathrm{C}_{\mathrm{TOC}}$ & $\mathrm{Ab} \mathrm{C} \mathrm{C} \mathrm{C}_{\mathrm{TOC}}$ & $\mathrm{F} \mathrm{C}_{\mathrm{TOC}}$ & Comb $\mathrm{C}_{\mathrm{TOC}}$ & Rot $\mathrm{C}_{\mathrm{TOC}}$ \\
\hline \multicolumn{8}{|c|}{$0-10 \mathrm{~cm}$} \\
\hline NT $C_{\text {micro }}$ & -0.418 & -0.395 & -0.351 & -0.143 & $-0.789 *$ & -0.142 & $-0.678 *$ \\
\hline RT $\mathrm{C}_{\text {micro }}$ & $-0.571 *$ & $-0.550^{*}$ & -0.558 & -0.371 & $-0.884 *$ & -0.323 & $-0.792 *$ \\
\hline CT $\mathrm{C}_{\text {micro }}$ & -0.289 & -0.285 & -0.278 & -0.0686 & $-0.757 *$ & -0.0173 & $-0.597 *$ \\
\hline $\mathrm{Ab} \mathrm{C}_{\text {micro }}$ & -0.463 & -0.437 & -0.393 & -0.201 & $-0.797 *$ & -0.186 & $-0.701 *$ \\
\hline $\mathrm{F} \mathrm{C}_{\text {micro }}$ & -0.269 & -0.255 & -0.212 & 0.00751 & $-0.700 *$ & 0.0125 & $-0.580 *$ \\
\hline Comb $\mathrm{C}_{\text {micro }}$ & -0.446 & -0.441 & -0.381 & -0.167 & $-0.802 *$ & -0.187 & $-0.700 *$ \\
\hline Rot $\mathrm{C}_{\text {micro }}$ & -0.177 & -0.165 & -0.158 & 0.0506 & $-0.680 *$ & 0.103 & -0.509 \\
\hline \multicolumn{8}{|c|}{$10-20 \mathrm{~cm}$} \\
\hline NT $C_{\text {micro }}$ & $-0.697 *$ & $-0.664 *$ & $-0.708 *$ & $-0.604 *$ & $-0.877 *$ & $-0.787^{*}$ & $-0.731 *$ \\
\hline RT $\mathrm{C}_{\text {micro }}$ & -0.229 & -0.405 & -0.324 & -0.157 & $-0.636^{*}$ & $-0.630 *$ & $-0.654 *$ \\
\hline CT $\mathrm{C}_{\text {micro }}$ & -0.221 & $-0.544^{*}$ & -0.522 & -0.135 & $-0.680 *$ & $-0.820 *$ & $-0.714 *$ \\
\hline $\mathrm{Ab} \mathrm{C}_{\text {micro }}$ & -0.258 & -0.411 & -0.503 & -0.182 & $-0.585^{*}$ & $-0.747 *$ & $-0.549 *$ \\
\hline $\mathrm{F} \mathrm{C}_{\text {micro }}$ & -0.0173 & $-0.639 *$ & -0.484 & -0.0712 & $-0.609 *$ & $-0.758 *$ & $-0.780 *$ \\
\hline Comb $\mathrm{C}_{\text {micr }}$ & -0.169 & -0.482 & -0.268 & -0.0977 & $-0.618 *$ & $-0.598^{*}$ & $-0.665^{*}$ \\
\hline Rot $\mathrm{C}_{\text {micro }}$ & -0.312 & -0.479 & -0.425 & -0.148 & $-0.622 *$ & $-0.736^{*}$ & $-0.552 *$ \\
\hline \multicolumn{8}{|c|}{$20-40 \mathrm{~cm}$} \\
\hline NT $\mathrm{C}_{\text {micro }}$ & $-0.660^{*}$ & $-0.644^{*}$ & $-0.591 *$ & -0.174 & -0.135 & $-0.553^{*}$ & -0.175 \\
\hline $\mathrm{RT} \mathrm{C}_{\text {micro }}$ & $-0.788^{*}$ & $-0.605^{*}$ & $-0.907 *$ & $-0.866^{*}$ & -0.413 & $-0.850 *$ & $-0.875^{*}$ \\
\hline CT $\mathrm{C}_{\text {micro }}$ & $-0.654^{*}$ & -0.492 & $-0.859 *$ & $-0.798^{*}$ & -0.358 & $-0.735^{*}$ & $-0.824^{*}$ \\
\hline $\mathrm{Ab} \mathrm{C}_{\text {micro }}$ & -0.405 & -0.141 & $-0.630 *$ & $-0.753^{*}$ & -0.440 & -0.508 & $-0.752 *$ \\
\hline $\mathrm{F} \mathrm{C}_{\text {micro }}$ & $-0.615^{*}$ & $-0.703^{*}$ & $-0.682 *$ & -0.308 & -0.0644 & $-0.578 *$ & -0.363 \\
\hline Comb $\mathrm{C}_{\text {micro }}$ & -0.506 & -0.363 & $-0.746^{*}$ & $-0.685^{*}$ & -0.347 & $-0.589 *$ & $-0.704^{*}$ \\
\hline Rot $\mathrm{C}_{\text {micro }}$ & $-0.865^{*}$ & $-0.671 *$ & $-0.942 *$ & $-0.845^{*}$ & -0.424 & $-0.871 *$ & $-0.836^{*}$ \\
\hline
\end{tabular}

$*$ indicates K. Pearson's coefficient significant differences at $\mathrm{P}<0.05(\mathrm{n}=12)$. 